\title{
A novel continuous feed and intermittent discharge airlift bioreactor (CFIDAB) for enhanced simultaneous removal of carbon and nutrients from soft drink industrial \\ wastewater
}

\author{
Azar Asadi $^{1}$, Ali Akbar Zinatizadeh ${ }^{1 *}$, Mark Van Loosdrecht $^{2}$ \\ ${ }^{1}$ Water and Wastewater Research Center (WWRC), Department of Applied Chemistry, Faculty of Chemistry, \\ Razi University, Kermanshah, Iran \\ Email: zinatizadeh@gmail.com, zinatizadeh@razi.ac.ir \\ ${ }^{2}$ Department of Biotechnology, Delft University of Technology, Julianalaan 67, 2628 BC Delft, the Netherlands
}




\begin{abstract}
Implementation of different redox zones is an interesting method to amend single bioreactors for the simultaneous nutrient removal process. Air lift bioreactors have been noticed recently as a system that could provide environments with different oxidation-reduction potentials (ORP). In this study, the performance of a novel continuous feed and intermittent discharge airlift bioreactor (CFIDAB) for simultaneous removal of nutrients ( $\mathrm{N}$ and $\mathrm{P}$ ) from soft-drink wastewater was investigated. Three independent variables were selected to analyze, model and optimize the process at three levels. The variables were hydraulic retention time (HRT) (6-14 h), the diameter ratio of internal and external column $\left(\mathrm{D}_{\text {in }} / \mathrm{D}_{\text {out }}\right)(0.3-0.7)$ (Corresponding to $10-1$ as surface area of downcommer and riser ratio), and dissolved oxygen (DO) concentration (0.5-3.5 $\mathrm{mg} / \mathrm{l})$. Three different zones; anaerobic, anoxic, and aerobic zones, were successfully provided in the bioreactor under continuous aeration. An industrial soft drink wastewater with COD:N:P of 100:16:5 was used as feed. The optimum condition was determined as $12 \mathrm{~h} \mathrm{HRT}$, a $\mathrm{D}_{\text {in }} / \mathrm{D}_{\text {out }}$ ratio of 0.5 and DO concentration of $3.5 \mathrm{mg} / \mathrm{l}$ At the optimum condition, COD, TN, and TP removal efficiencies were 98, 72, and 65\%, respectively. Performance of the CFISAB is extremely influenced by superficial gas velocity due to its direct impact on development of different zones in the single bioreactor. As a conclusion, this innovative single bioreactor is capable to treat wastewaters with high content of carbon and nutrients in smaller volume compared to existing conventional and combined systems.
\end{abstract}

Keywords: Airlift bioreactor, continuous feed and intermittent discharge (CFID), simultaneous nutrients removal, soft drink wastewater. 


\section{Introduction}

Due to industrialization and activities in recent years, the discharge of wastewater containing nutrients has been a common problem all over the world as reported in the USA, France, Morocca, Canada, Turkey, and Egypt [1-5]. Therefore, regulations are implemented to control the concentration of nutrients in the environment. Biological treatment, the most common method used in wastewater treatment plants, has attracted considerable interests to nutrients removal through the combination of different circumstances required for nitrogen and phosphorus removal consisting of anaerobic, aerobic and anoxic zones [6].

The high rate bioreactors specialized for nutrients removal could be classified into two categories: multi-stage bioreactors and single-stage bioreactors. Single-stage bioreactors reduce the operational cost, required energy and volume compared to multi-stage bioreactors. Single bioreactors are operated through intermittent aeration strategy or physical separation. Physical separation is a promising method to amend single bioreactors for providing an easy continuous operation. In physical separation approach, different zones for CNP removal could be provided in a single bioreactor with continuous aeration by inserting a barrier like internal tube and baffles $[7]$.

The hydraulic regime of bioreactors is a crucial factor influencing the removal efficiency of bioreactors. Continuous regime bioreactors are more applied for large wastewater treatment plant with high influent flow rate. Some of the continuous single bioreactors applying physical separation were employed to treat various wastewaters i.e. loop membrane bioreactor (JLMBR) for treating cheese whey wastewater [8], bubble column with a draught tube to treat synthetic wastewater [9], a biofilm airlift suspension extension reactor to treat synthetic wastewater [10], 
radial anaerobic-aerobic immobilized biomass (RAAIB) bioreactor to treat sewage wastewater [11], simultaneous anaerobic-aerobic (SAA) bioreactor for treating diluted land filled leachate [12], an airlift loop reactor under a limited filamentous bulking state for treating synthetic wastewater [13], airlift intermittent circulation membrane bioreactor for treating synthetic wastewater [14].

Sequencing batch reactor (SBR) is a prominent operation mode of activated sludge system utilized in small wastewater treatment plants. This reactor does not need clarifier and flow equalization tank which make it a good rival to continuous systems, certainly for smaller industries [11, 15-19]. Over the years SBR has been developed and combined with other technologies. In a study, biological removal of phenol from a strong wastewater in a moving bed sequencing batch reactor (MBSBR) was studied. The optimum hydraulic retention time (HRT) for the MBSBR with a critical phenol loading rate of $83.4 \mathrm{~g}$ phenol/ $\mathrm{m}^{3} . \mathrm{h}$ was determined to be $40 \mathrm{~h}$ where $99 \%$ of the phenol contents was removed [20]. A fixed-bed SBR (FBSBR) was also applied for the treatment of synthetic domestic wastewater in a research work [21]. Chemical oxygen demand (COD) and total nitrogen (TN) and phosphorus removal efficiencies at the range of $90-96 \%, 60-88 \%$, and 76-90\%, respectively were reported.

Shuai Yang and his co-workers operated a sequencing batch moving bed membrane bioreactor (SBMBMBR) at different $\mathrm{COD} / \mathrm{TN}$ ratios. $\mathrm{COD}, \mathrm{TN}$ and ammonium nitrogen removal efficiencies averaged at $93.5 \%, 82.6 \%$ and $95.6 \%$, respectively [22].

A new generation of SBR is continuous feed and intermittent discharge SBR (CFID SBR) which is a mixture of continuous and batch regimes having the features of both reactor types. An up flow anoxic aerobic sludge bed (UAASB) bioreactor derived from CFID SBR was investigated for removing CNP from an industrial wastewater. 91\%, 60\% and 32\% of COD, TN and TP 
removal were reported, respectively, at HRT of $12 \mathrm{~h}$ and aeration time of $40 \mathrm{~min} / \mathrm{h} \mathrm{[23].} \mathrm{To}$ explore potential of the CFID regime in simultaneous removing carbon and nutrients from wastewater in comparison to batch mode, Asadi and coworkers operated SBR and CFID bioreactors at the same experimental conditions [24]. Based on the experimental results, CFID was more efficient in removing carbon and nitrogen, whereas SBR had a better performance to eliminate phosphorus compounds [24]. In another study, CFID bioreactor was augmented by high-frequency ultrasonic treatment for treating milk processing wastewater, more than $50 \%$ removal efficiency was reported for nutrients and 90\% for soluble COD (sCOD) at the optimum condition (12-15 h, 4000-5000 mg/l and 1.5-2 for HRT, MLSS concentration and aeration mode, respectively) [25]. It must be noted that in the mentioned studies, intermittent aeration was the strategy for removing CNP. In these systems, the aeration time was adjusted to provide aerobic, anoxic, and anaerobic conditions.

Another single bioreactor capable to supply different zones in terms of DO concentration is air lift bioreactor. From the literature, air lift bioreactor was particularly utilized to remove nitrogen components $[14,26]$. A continuous-flow airlift internal circulation membrane bioreactor proposed to eliminate nitrogen from synthetic wastewater. About $70 \%$ of nitrogen content was removed at $\mathrm{HRT}$ of $12 \mathrm{~h}, \mathrm{COD} / \mathrm{N}$ ratio of 10.04 and DO concentration of $1 \mathrm{mg} / \mathrm{l}$ [27]. It should be noted that the hydraulic regime applied for air lift bioreactor has been batch and continuous mode up to this date which with the modes of operation used, the air lift bioreactors were not proficient to provide anaerobic zone.

In the present study, the performance of a continuous feed and intermittent discharge airlift bioreactor (CFIDAB) bioreactor derived from CFID SBR as an innovative single reactor in removing carbon and nutrients was investigated. The assumption is to provide anaerobic, anoxic, 
and aerobic conditions simultaneously in this novel single air lift bioreactor. The experimental conditions were designed by design expert software based on four independent variables viz. hydraulic retention time (HRT), the diameter ration of internal and external column $\left(\mathrm{D}_{\text {in }} / \mathrm{D}_{\text {out }}\right)$, and dissolved oxygen (DO) concentration. Seven responses comprising sCOD removal, TN removal, effluent $\mathrm{NO}_{3}{ }^{-}$, effluent $\mathrm{NO}_{2}{ }^{-}$, TP removal, sludge volume index (SVI), effluent turbidity were measured as process response to analyze and model the process performance.

\section{Materials and methods}

\subsection{Wastewater characteristics}

Soft drink industrial wastewater was collected from a working soft drink processing production plant (Zamzam Co., Kermanshah, Iran) every three days. Table 1 shows characteristics of the wastewater. The samples were stored at $4{ }^{\circ} \mathrm{C}$ to preserve the samples and avoid considerable changes in the wastewater characteristics. $\mathrm{NH}_{4} \mathrm{Cl}$ and $\mathrm{KH}_{2} \mathrm{PO}_{4}$ were used to adjust different $\mathrm{C} / \mathrm{N} / \mathrm{P}$ ratios.

\begin{tabular}{lll}
\multicolumn{2}{c}{ Table 1.Characteristics of soft drink industrial wastewater. } \\
\hline Parameters & Unit & Amount \\
\hline sCOD & $(\mathrm{mg} / \mathrm{l})$ & $945-1200$ \\
$\mathrm{BOD}_{5}$ & $(\mathrm{mg} / \mathrm{l})$ & $756-960$ \\
$\mathrm{~N}^{+} \mathrm{NH}_{4}{ }^{-}$ & $(\mathrm{mg} / \mathrm{l})$ & $140-150$ \\
$\mathrm{~N}-\mathrm{NO}_{3}{ }^{-}$ & $(\mathrm{mg} / \mathrm{l})$ & $19-21$ \\
$\mathrm{TN}$ & $(\mathrm{mg} / \mathrm{l})$ & $159-171$ \\
$\mathrm{TP}$ & $(\mathrm{mg} / \mathrm{l})$ & $46-50$ \\
pH & - & $7.5-8.5$ \\
\hline
\end{tabular}

\subsection{Bioreactor configuration and process description}

The schematic of the CFIDAB bioreactor is shown in Fig. 1. The main column was fabricated with an internal diameter of $10 \mathrm{~cm}$ and height of $140 \mathrm{~cm}$. The working volume was 5.31 with $120 \mathrm{~cm}$ height. A submerged column was located in the bioreactor with the height of $75 \mathrm{~cm}$ and 
different diameters. At the height of $50 \mathrm{~cm}$ (40\% of the total volume), an automatic control valve was fixed on the reactor body to discharge the effluent intermittently. The discharge height was selected at a point $25 \mathrm{~cm}$ lower relative to upper edge of the internal column to avoid any circulation between inner (riser) and outer (downcomer) content of the submerged column for a sometime at the beginning of each cycle. When the outlet is closed (at the end of the discharge step) (Fig. 1a), the anaerobic condition is gradually developed at the non-aerated part while feeding continues (Fig. 1b) till the liquid level reaches the edge of the internal column (Fig. 1c). Duration of this period depends on the influent flow rate (or HRT), e.g. $1.5 \mathrm{~h}$ for a HRT of $10 \mathrm{~h}$ (Fig. 1c). The feed was introduced into the bioreactor from down comer region. Two mixers were used in the descending pipe to provide sufficient mixing during anaerobic phase (with no circulation) (Fig. 1a). Circulation is started when the liquid level reaches the edge of the internal tube (Fig. 1c). At this condition, the down comer region turns to anoxic/aerobic conditions depending the air and influent flow rate (Fig. 1d and e).

Air was supplied into the submerged tube by a blower connected to a fine air bubble diffuser from the bottom of the tube. HRT was calculated based on $1.5 \mathrm{~L}$ of feeding volume (the volume which is filled and discharged). An air flow-meter and a timer were connected to the blower to control the air flow rate and aeration time, respectively. 


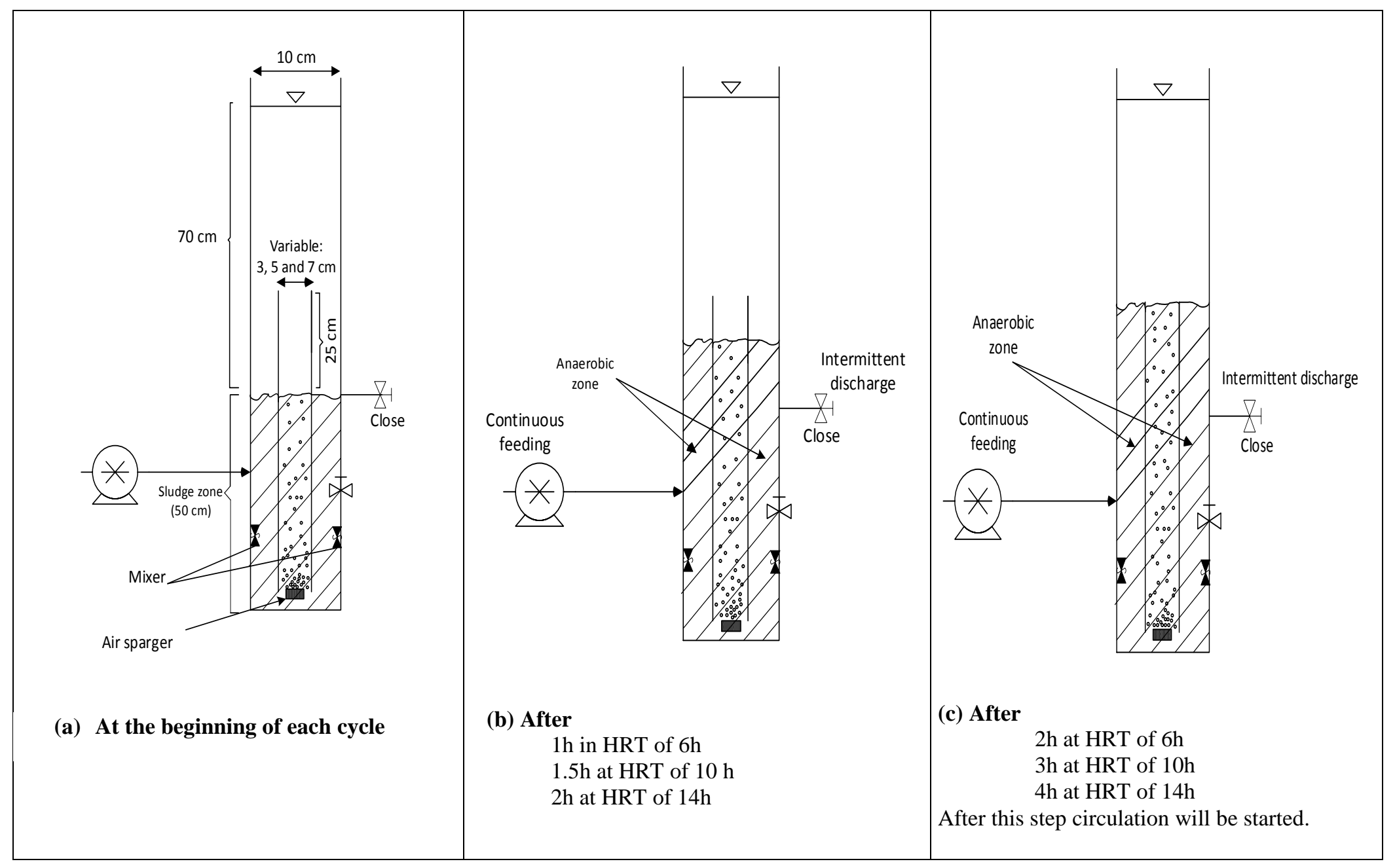




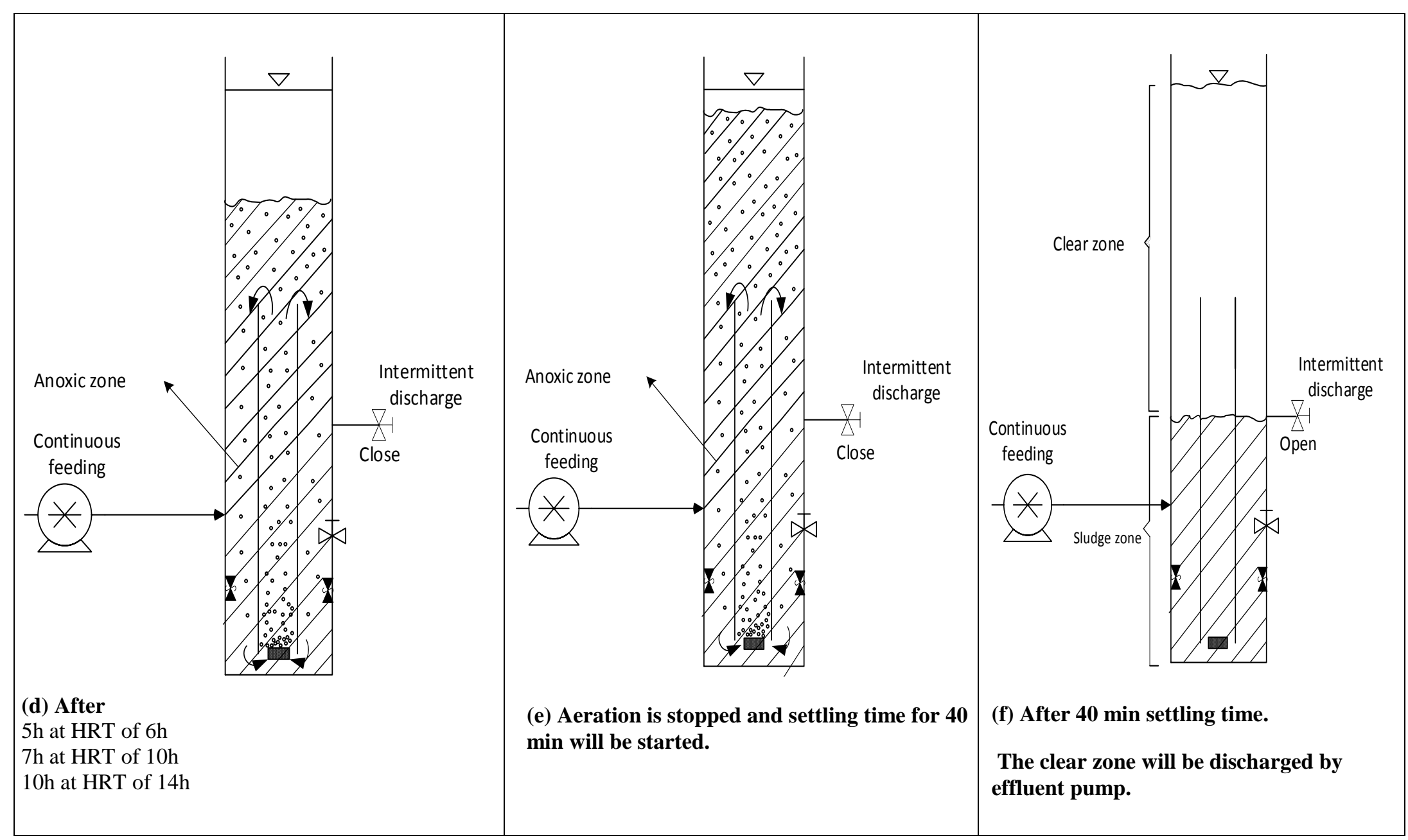

Fig. 1. The lab scale CFIDAB used in this study at different operating step. 


\subsection{Bioreactor operation}

This bioreactor was operated for 10 months continuously. The CFIDAB bioreactor was fed continuously from the bottom of the main column. The treated effluent was intermittently discharged after settling as supernatant at end of each experiment. The CFIDAB was operated under room temperature $\left(20 \pm 2^{\circ} \mathrm{C}\right)$.

In the first stage, the CFIDAB was inoculated with activated sludge taken from soft drink wastewater treatment plant and operated at HRT and MLSS of $6 \mathrm{~h}, 6000 \mathrm{mg} / \mathrm{l}$, respectively. This condition was sustained to achieve a steady state. Steady state condition was achieved after 4 or 5 days of operation with ignorable variation in the process performance in terms of CNP removal efficiencies. Afterwards, the bioreactor was operated according to conditions designed by Design Expert Software (DOE) (Stat-Ease Inc., version 7.0). The experimental runs were designed based on three independent variables including: $\operatorname{HRT}(6,10$ and $14 \mathrm{~h}), \mathrm{D}_{\text {in }} / \mathrm{D}_{\text {out }}(0.3,0.5$ and 0.7 corresponding to 10-1 as surface area of downcommer and riser ratio), and DO concentration $(0.5,2,3.5 \mathrm{mg} / \mathrm{l})$. The settling time for all runs was 40 minutes. DO adjustment was conducted based on a preliminary experiment at different operating conditions as DO is influenced by varying in organic loading load (OLR) during an operation cycle in the bioreactor.

Each run was continued about 10 days to get adapted microorganism populations and the responses under a steady state condition. In order to start a new run, TP absorbed in the phosphorus accumulating organisms (PAOs) was released and discharged under an anaerobic condition applied in the bioreactor after each run. To provide the anaerobic condition required for the phosphorous release, the bioreactor was filled with fresh wastewater with COD concentration and retention time of $2000 \mathrm{mg} / \mathrm{l}$ and $5 \mathrm{~h}$, respectively. After that, the bioreactor operation was conducted based on the experimental conditions designed. In the second stage, the 
bioreactor was operated at the optimum condition for a 60 -cycle run (30 days) to monitor the phosphorus removal efficiency over long time.

\subsection{Experimental design}

Statistical design of experiments and data analysis were carried out by Design Expert Software (version 7.0). Three independent effective variables, HRT, $\mathrm{D}_{\mathrm{in}} / \mathrm{D}_{\text {out }}$, and DO concentration were selected in the experiments design. The range and levels of the variables in coded and actual units are given in Table 2. The three physical and operating variables were considered at three levels. In the basis of the factorial design, 20 experiments were designed (Table 2).

Table 2. Experimental range and conditions of the independent variables.

\begin{tabular}{|c|c|c|c|}
\hline \multirow[t]{2}{*}{ Variables } & \multicolumn{3}{|c|}{ Range and levels } \\
\hline & -1 & 0 & +1 \\
\hline HRT, h & 6 & 10 & 12 \\
\hline $\mathbf{D}_{\text {in }} / \mathbf{D}_{\text {out }}$ & 0.3 & 0.5 & 0.7 \\
\hline Dissolved oxygen (DO), mg/l & 0.5 & 2 & 3.5 \\
\hline \multicolumn{4}{|c|}{ Experimental conditions } \\
\hline Run no & $\begin{array}{l}\text { Factor 1 } \\
\text { HRT (h) }\end{array}$ & $\begin{array}{l}\text { Factor } 2 \\
D_{\text {in }} / D_{\text {out }}\end{array}$ & $\begin{array}{l}\text { Factor } 3 \\
\text { DO conc. }(\mathrm{mg} / \mathrm{l})\end{array}$ \\
\hline 1 & 6 & 0.3 & 3.5 \\
\hline 2 & 6 & 0.3 & 0.5 \\
\hline 3 & 10 & 0.3 & 2 \\
\hline 4 & 14 & 0.3 & 3.5 \\
\hline 5 & 14 & 0.3 & 0.5 \\
\hline 6 & 6 & 0.5 & 2 \\
\hline 7 & 10 & 0.5 & 3.5 \\
\hline 8 & 10 & 0.5 & 2 \\
\hline 9 & 10 & 0.5 & 0.5 \\
\hline 10 & 14 & 0.5 & 2 \\
\hline 11 & 6 & 0.7 & 3.5 \\
\hline 12 & 6 & 0.7 & 0.5 \\
\hline 13 & 10 & 0.7 & 2 \\
\hline 14 & 14 & 0.7 & 3.5 \\
\hline 15 & 14 & 0.7 & 0.5 \\
\hline 16 & 10 & 0.5 & 2 \\
\hline 17 & 10 & 0.5 & 2 \\
\hline 18 & 10 & 0.5 & 2 \\
\hline 19 & 10 & 0.5 & 2 \\
\hline 20 & 10 & 0.5 & 2 \\
\hline
\end{tabular}




\subsection{Analytical methods}

The concentrations of COD, biological oxygen demand (BOD), TN, nitrate and nitrite, $\mathrm{NH}_{4}-\mathrm{N}$, TP, and MLSS were determined by using standard methods [28]. For COD, a colorimetric method with closed reflux method was developed (5220 D). Spectrophotometer (DR 5000, Hach, Jenway, USA) at $600 \mathrm{~nm}$ was used to measure the absorbance of COD samples. $\mathrm{N}-\mathrm{NH}_{4}$ were determined by TKN meter Gerhardt model (Vapodest 10, Germany). The DO concentration in wastewater was determined using a DO probe supplied by WTW DO Cell OX 330, electro DO probe, Germany. Turbidity was measured by a turbidity meter model 2100 P (Hach Co., USA). Air flow rate was measured by an air flow meter model 101325Pa, respectively.

\subsection{Statistical analysis}

As various responses were investigated in this study, different degrees of polynomial models were used for data fitting (Table 3). The regression equations obtained are presented in Table 3. In order to quantify the curvature effects, the data from the experimental results were fitted to higher degree polynomial equations, i.e. two-factor interaction (2FI) and quadratic. In the Design Expert Software, the response data were analyzed by default. The ANOVA results for all responses have been summarized in Table 3. The model terms in the equations are after elimination of insignificant variables and their interactions. Based on the statistical analysis, the models were highly significant with very low probability values $(<0.0001)$. It was shown that the model terms of independent variables were significant at the $99 \%$ confidence level. The square of correlation coefficient for each response was computed as the coefficient of determination $\left(\mathrm{R}^{2}\right)$ which it was in the range of 0.81-0.91 for the obtained data in this study. The models adequacy was tested through lack-of-fit F-tests [29]. The lack of fit F-statistic was not 
statistically significant as the P-values were greater than 0.05 , indicating a proper model to fit predicted data with actual data.

Adequate precision is a measure of the range in predicted response relative to its associated error or, in other words, a signal-to-noise ratio. Its desired value is 4 or more [30]. The value was found desirable for all models. Simultaneously, low values of the coefficient of variation (CV) $(2.79-136.97 \%)$ indicated good precision and reliability of the experiments as suggested by Kuehl [31] and Khuri and Cornell [32]. In order to check the accuracy and precision of the models used in this study, more statistical analysis was done as shown in Fig. 2. The normal probability graphs of residuals are plotted for SCOD removal, TN removal, TP removal, and effluent turbidity as shown in Figs. 2 a, c, e, and g, respectively. The normal probability plot is a graphical technique for assessing whether or not a data set is approximately normally distributed. In a normal probability plot, the sorted data are plotted vs. values selected to make the resulting image look close to a straight line if the data are approximately normally distributed. Deviations from a straight line suggest departures from normality. It is seen that the residuals are falling in a straight line for all responses, which indicate that the errors are normally distributed [33]. Also, Figs. 2 b, d, f, and h, illustrate the plots of cook's distance for the responses. Cook's distance is a measure how much the regression equation changes if a case is deleted which can be used to identify individual runs that may be outlier. Also, Cook's distance can be used in several ways for instance to indicate data points that are particularly worth checking for validity and to indicate regions of the design space where it would be good to be able to obtain more data points.

From the figure, the most of the operating conditions have a distance lower than 0.25 which proves the accuracy of the model and the correct range of design points [34]. 
Table 3. ANOVA results for the regression equations obtained for the studied responses.

\begin{tabular}{|c|c|c|c|c|c|c|c|c|c|}
\hline Response & Modified Equations with significant terms & Probability & $\mathbf{R}^{2}$ & Adj. $\mathbf{R}^{2}$ & $\begin{array}{l}\text { Adeq. } \\
\text { precision }\end{array}$ & S.D & $\mathbf{C V}$ & PRESS & $\begin{array}{l}\text { Probability } \\
\text { for lack of fit }\end{array}$ \\
\hline sCOD removal & $99.23+3.5 \mathrm{~A}+1.7 \mathrm{~B}+2.20 \mathrm{C}-3.62 \mathrm{~B}^{2}-3.12 \mathrm{C}^{2}$ & $<0.0001$ & 0.9005 & 0.8649 & 18.550 & 1.74 & 1.81 & 92.14 & 0.1284 \\
\hline TN removal & $+54.10+8.30 \mathrm{~A}+6.10 \mathrm{~B}+13.60 \mathrm{C}+5.25 \mathrm{AC}-8.00 \mathrm{~A}^{2}$ & $<0.0001$ & 0.9135 & 0.8826 & 21.16 & 0.045 & 9.64 & 647.58 & 0.1848 \\
\hline TP removal & $+63.70+8.20 \mathrm{~A}+8.10 \mathrm{~B}+3.90 \mathrm{C}-10.62 \mathrm{AB}-4.70 \mathrm{~A}^{2}$ & $<0.0001$ & 0.8183 & 0.7345 & 11.803 & 6.90 & 10.68 & 1131.91 & 0.1445 \\
\hline Effluent turbidity & $+14.00-4.20 \mathrm{~A}-5.70 \mathrm{~B}-9.50 \mathrm{C}+3.25 \mathrm{AC}+5.00 \mathrm{BC}+5.5 \mathrm{~B}^{2}$ & $<0.0001$ & 0.9001 & 0.8540 & 18.190 & 3.96 & 23.66 & 527.72 & 0.2184 \\
\hline
\end{tabular}




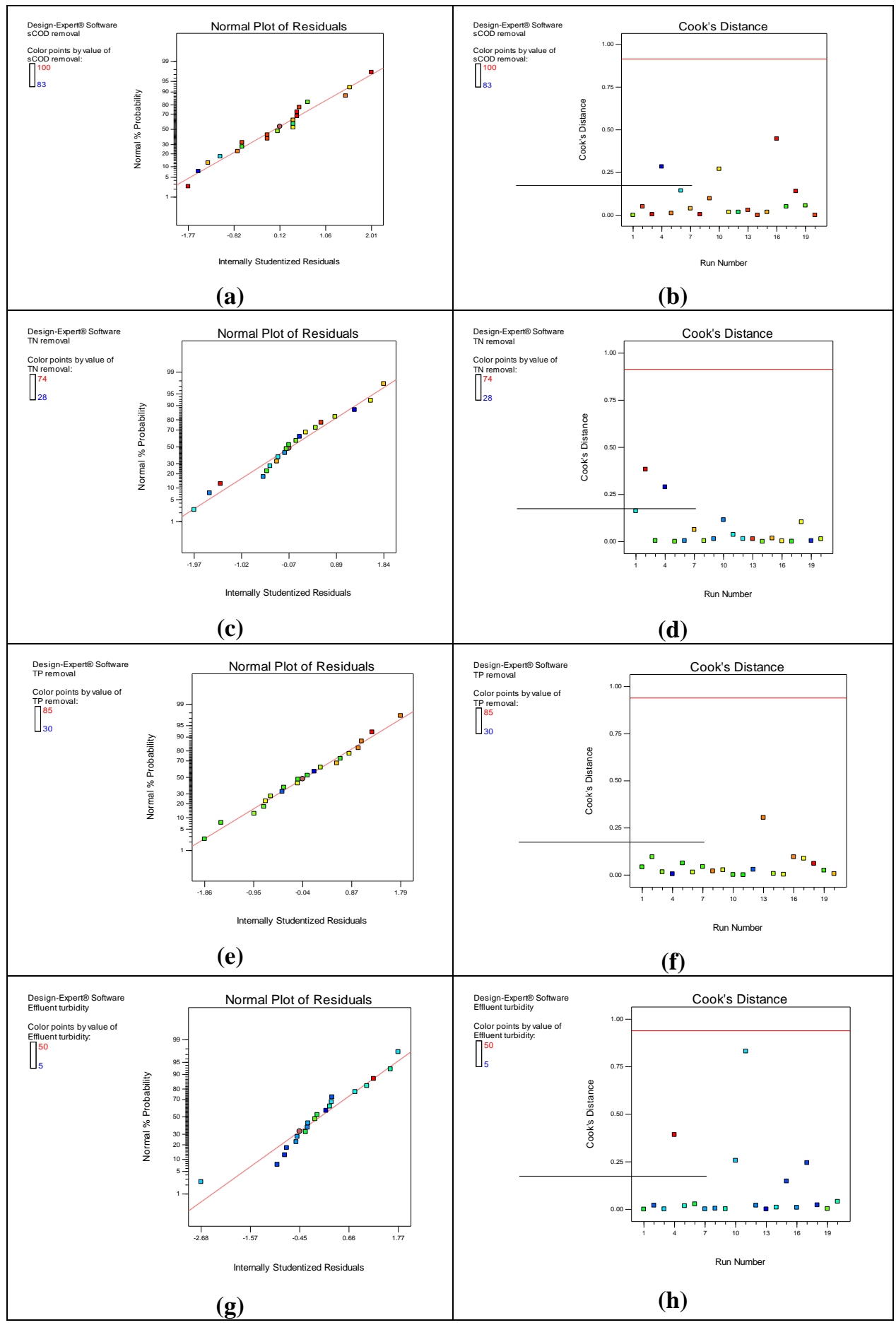

Fig. 2. Residuals normal probability plot and cook's distances for COD removal (a and b), TN removal (c and d), TP removal (e and $\mathrm{f}$ ), and effluent turbidity ( $\mathrm{g}$ and $\mathrm{h}$ ). 


\section{Results and discussion}

\subsection{Process performance}

In order to evaluate the process performance, 10 process responses were measured or calculated over 20 experiments with different experimental conditions. The experimental results are shown in Table 4.

Table 4. Experimental conditions and results.

\begin{tabular}{|c|c|c|c|c|c|c|c|c|c|c|c|c|}
\hline \multirow[b]{2}{*}{ Run } & \multicolumn{3}{|c|}{ Variables } & \multicolumn{8}{|c|}{ Responses } & \multirow[b]{2}{*}{$\begin{array}{c}\text { Superficial } \\
\text { Gas velocity } \\
\text { m/min }\end{array}$} \\
\hline & $\begin{array}{c}\text { Factor1 } \\
\text { A:HRT, } \\
\text { h }\end{array}$ & $\begin{array}{c}\text { Factor2 } \\
\text { B: } \mathbf{D}_{\text {in }} / \mathbf{D}_{\text {out }}\end{array}$ & $\begin{array}{c}\text { Factor } 3 \\
\text { C: } \begin{array}{c}\text { DO conc. } \\
\text { mg/l }\end{array}\end{array}$ & $\begin{array}{c}\text { sCOD } \\
\text { removal, } \\
\%\end{array}$ & $\begin{array}{c}\text { TN } \\
\text { removed, } \\
\text { mg/l }\end{array}$ & $\begin{array}{c}\text { TN } \\
\text { removal, } \\
\%\end{array}$ & $\begin{array}{c}\text { Effluent } \\
\mathrm{N}-\mathrm{NO}_{3}, \\
\mathrm{mg} / \mathrm{l}\end{array}$ & $\begin{array}{c}\text { Effluent } \\
\mathrm{N}^{-N O_{2}}, \\
\text { mg/l }\end{array}$ & 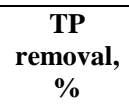 & $\begin{array}{c}\text { Effluent } \\
\text { Turbidity, } \\
\text { NTU }\end{array}$ & $\begin{array}{c}\text { Air flow rate, } \\
1 \text { air/ } \mathrm{min}\end{array}$ & \\
\hline 1 & 6 & 0.3 & 3.5 & 91 & 47.61 & 32 & 12.49 & 0.9 & 35 & 11 & 3 & 4.24 \\
\hline 2 & 6 & 0.3 & 0.5 & 84 & 34.19 & 22 & 1.2 & 0.001 & 30 & 50 & 0.6 & 0.849 \\
\hline 3 & 10 & 0.3 & 2 & 94 & 64.2 & 40 & 1.28 & 0.001 & 60 & 25 & 1.25 & 1.769 \\
\hline 4 & 14 & 0.3 & 3.5 & 97 & 100.5 & 64 & 0.5 & 0 & 70 & 8 & 1.25 & 1.769 \\
\hline 5 & 14 & 0.3 & 0.5 & 93 & 40 & 25 & 0.5 & 0 & 61 & 32 & 0.5 & 0.707 \\
\hline 6 & 6 & 0.5 & 2 & 94 & 56.2 & 35 & 3.31 & 0.001 & 50 & 19 & 1.25 & 0.636 \\
\hline 7 & 10 & 0.5 & 3.5 & 100 & 115 & 72 & 1.26 & 0 & 80 & 5 & 1.25 & 0.636 \\
\hline 8 & 10 & 0.5 & 2 & 100 & 54 & 34 & 0.95 & 0 & 65 & 15 & 0.85 & 0.433 \\
\hline 9 & 10 & 0.5 & 0.5 & 96 & 53 & 46 & 0.67 & 0 & 60 & 14 & 0.5 & 0.254 \\
\hline 10 & 14 & 0.5 & 2 & 100 & 98.83 & 62 & 0.39 & 0.09 & 92 & 7 & 0.75 & 0.382 \\
\hline 11 & 6 & 0.7 & 3.5 & 92 & 88 & 53 & 3.43 & 0.08 & 71 & 8 & 1.5 & 0.389 \\
\hline 12 & 6 & 0.7 & 0.5 & 86 & 57.87 & 35 & 2.13 & 0 & 58 & 25 & 0.5 & 0.129 \\
\hline 13 & 10 & 0.7 & 2 & 100 & 101 & 62 & 4.7 & 0.162 & 78 & 12 & 0.6 & 0.155 \\
\hline 14 & 14 & 0.7 & 3.5 & 99 & 122 & 74 & 5.4 & 0 & 62 & 9 & 0.6 & 0.155 \\
\hline 15 & 14 & 0.7 & 0.5 & 96 & 66 & 40 & 3 & 0 & 58 & 15 & 0.4 & 0.104 \\
\hline
\end{tabular}




\subsection{1 sCOD removal}

In this study, sCOD removal efficiency was monitored as a response to evaluate the capability of the system to treat soft drink industrial wastewater. A reduced quadratic model described the variation of sCOD removal efficiency as a function of the variables. The ANOVA values for sCOD removal efficiency are presented in Table 4. The significance of each coefficient was determined by F-value and P-value. From the table, A, B, C, B ${ }^{2}$, and $\mathrm{C}^{2}$ were significant model terms where $\mathrm{A}, \mathrm{B}$, and $\mathrm{C}$ are the symbol of $\mathrm{HRT}, \mathrm{D}_{\mathrm{in}} / \mathrm{D}_{\text {out }}$, and DO concentration, respectively. Variance inflation factor (VIF) is a statistical parameter which represents the degree of individuality of the factors. In other words, VIF shows how much the variance of the model is inflated by the lack of orthogonality in the design. VIF value of one implies the factor is orthogonal to all other factors in the model. VIF value for factors of A and B is 1 , and for the rest of the model terms is 1.56 .

The effects of HRT and $\mathrm{D}_{\text {in }} / \mathrm{D}_{\text {out }}$ on the response at different DO concentrations are shown in Figures 3a, b, and c, respectively. From the Figs., the bioreactor showed an excellent performance to eliminate sCOD, with more than $80 \%$ of the response at different operating conditions studied.

The high sCOD removal efficiency could be explained by three reasons; one is related to high biodegradability of the wastewater $\left(\mathrm{BOD}_{5} / \mathrm{COD}\right.$ ratio of about 0.82) [19]. Second might be resulted from the CFID regime applied, the system is operated with a constant F/M while dilution rate is gradually increased to two times of a similar system with continuous regime, providing a condition almost similar to feast-famine phases in a batch system. The third reason can be linked to the nature of air lift bioreactors and the circulation between inside and outside of 
the draught column, resulting a longer air contact time in liquid which increases the efficiency of oxygen bubbles in the bioreactor $[35,36]$.

The DO concentration depicts an increasing effect on the response. The higher values of SCOD removal efficiency (more than 96\%) were obtained mostly at the conditions with high DO concentration $(>2 \mathrm{mg} / \mathrm{l})$. It is found from the figures that $\mathrm{D}_{\text {in }} / \mathrm{D}_{\text {out }}$ showed a reverse impact at values up to 0.5 , respectively at all DO concentrations. $D_{\text {in }} / D_{\text {out }}$ had an increasing effect on the response with increasing $\mathrm{D}_{\text {in }} / \mathrm{D}_{\text {out }}$ from 0.3 to 0.5 , however, further increasing in $\mathrm{D}_{\text {in }} / \mathrm{D}_{\text {out }}$ led to a decreasing trend of the response. This might be due to releasing soluble microbial products (SMP) at this condition which oxidation potential was high. 


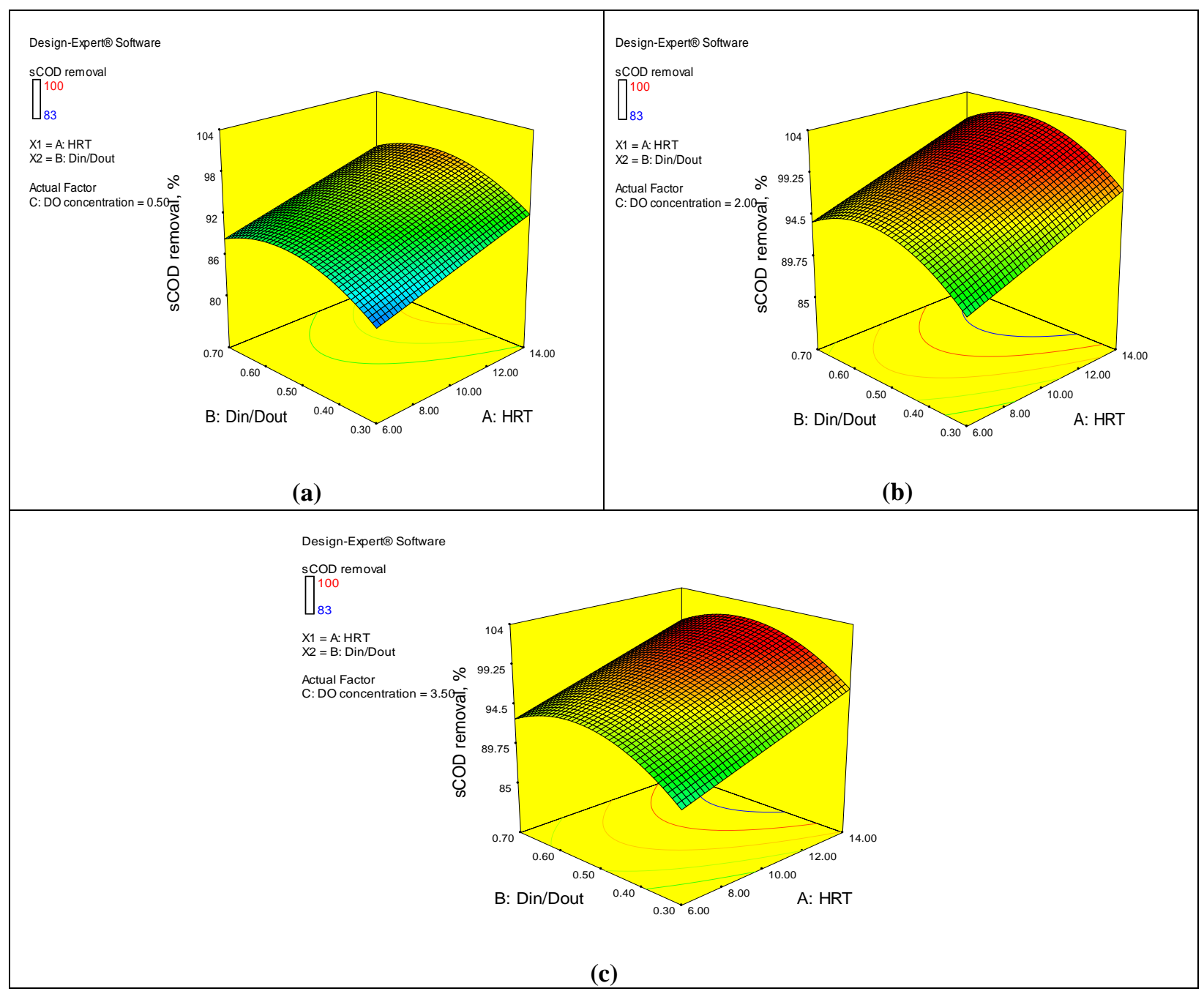

Fig. 3. Response surface plots for sCOD removal efficiency as a function of HRT and $D_{\text {in }} / D_{\text {out }}$ at different DO concentrations: (a) 0.5 , (b) 2 , (c) $3.5 \mathrm{mg} / \mathrm{l}$.

\subsubsection{TN removal}

One of the main environmental concerns in the developing countries is the discharge of high concentration of nitrogen and phosphorus compounds into the environment. The concentration of nitrogen compounds discharged from human activities is relatively high, particularly in domestic, agricultural and some of industrial wastewaters generated from food and chemical industries [37]. Hence, one of the attractive aspects in biological wastewater treatment is to provide appropriate conditions for nitrogen removal from wastewater in a single bioreactor, 
nowadays [7, 38]. In this study, different conditions for nitrogen removal were provided through physical separation (inserting an internal tube in a CFID SBR based bioreactor). The ANOVA values for TN removed are presented in Table 3. A reduced quadratic model was selected to describe the variation of the response. From table 3, A, B, C, AC, and $\mathrm{A}^{2}$ are significant model terms. Other model terms were not significant (with a probability value larger than 0.05 ) and eliminated to simplify the model. Besides, VIF value for all model terms are 1. Therefore, VIFA values of the model terms prove the reliability of the applied model for TN removal.

Figs. $4 \mathrm{a}, \mathrm{b}$, and $\mathrm{c}$ show the three dimensional plots of the response as a function of HRT and DO concentrations at different values of $\mathrm{D}_{\text {in }} / \mathrm{D}_{\text {out }}$. A similar altering trend for $\mathrm{TN}$ removal was found at different $\mathrm{D}_{\text {in }} / \mathrm{D}_{\text {out }}$. From the results, DO concentration had a positive effect on TN removal. This result shows that higher DO concentration caused an improvement in nitrification process which led to more TN removal efficiency, demonstrating high capacity of the bioreactor for denitrification process. From the model presented in table 4, AC is the only interactive term effective on the response. The interactive effect of HRT and DO concentration at $\mathrm{D}_{\text {in }} / \mathrm{D}_{\text {out }}$ of 0.5 is depicted in Fig. 4d. As is obvious, the AC had an increasing impact on the TN removal efficiency. The variables showed increasing effect on the response with different rate. DO concentration was found to be crucial factor with more increasing effect relative to the other variables. In order to clarify the fate of nitrogen contents during the bioprocess, contribution of synthesis, nitrification and denitrification processes in biological nitrogen removal at different operating conditions were determined and the results are shown in Fig. 5. From the figure, the lowest level of $\mathrm{D}_{\text {in }} / \mathrm{D}_{\text {out }}$ had the maximum portion of synthetic process rather than denitrification process in removing nitrogen content (runs no. 1, 2, 3, and 5). It might be because of high circulation speed at the lowest $D_{\text {in }} / \mathrm{D}_{\text {out }}$, restricting anoxic zone (superficial gas velocity of 4.2 
$\mathrm{m} / \mathrm{min}$ ). In fact, at the lowest $\mathrm{D}_{\text {in }} / \mathrm{D}_{\text {out }}$, aeration was occurred in smaller zone which needs higher air flow rate to provide the required DO concentration relative to larger $\mathrm{D}_{\mathrm{in}} / \mathrm{D}_{\text {out }}$ (Table 3). Higher air flow rate caused higher superficial gas velocity and circulation speed between inside and outside of the internal column.

Another point found from the figure is increase in the $\mathrm{N}$ removal due to denitrification process resulted from an increase in HRT at constant DO (decrease in air flow rate) (runs no. 1 and 4 at 0.3 of $\mathrm{D}_{\text {in }} / \mathrm{D}_{\text {out }} ; 6$ and 8 at 0.5 of $\mathrm{D}_{\text {in }} / \mathrm{D}_{\text {out }} ; 11$ and 14 at 0.7 of $\mathrm{D}_{\text {in }} / \mathrm{D}_{\text {out }}$, implying an improvement in the balance between the nitrification and denitrification processes. This fact can be explained with increasing in circulation turnover rates between aerobic and anoxic zones and also a reduction in superficial gas velocity by lower air flow rate. The data of superficial gas velocity at different air flow rate and Din/Dout is presented in Fig. 6. The superficial gas velocity was calculated according to Eq.1:

$$
J_{G}=\frac{Q}{A_{r}}
$$

Eq. 1

where, $J_{G}$ is gas superficial velocity $(\mathrm{m} / \mathrm{min})$, $Q$ is air flow rate $\left(\mathrm{m}^{3} / \mathrm{min}\right)$, and $A_{r}$ is crosssectional area of riser zone $\left(\mathrm{m}^{2}\right)$.

This should be noted that DO concentration remained constant at different HRTs by altering the air flow rate at a constant $D_{\text {in }} / D_{\text {out }}$. In other words, the amount of food to microorganism (F/M) ratio is decreased with increasing HRT, requiring less air flow rate to provide DO concentration compared to low HRTs. Besides, DO concentration showed a positive effect on the denitrification process at a constant $\mathrm{HRT}$, implying more $\mathrm{NO}_{3}{ }^{-}$concentration as a substrate for denitrification process. An exception was found at the highest $D_{\text {in }} / D_{\text {out }}$ and HRT (runs no. 14 and 
15), where an increase in the DO concentration from 0.5 to $3.5 \mathrm{mg} / \mathrm{l}$ triggered a decrease in denitrification process as a result of an inadequate anoxic condition.

Generally, the effluent $\mathrm{NO}_{3}{ }^{-}$concentration was lower than $5 \mathrm{mg} / \mathrm{l}$ at most operating conditions, indicating an effective anoxic condition. The obtained results showed that the innovative design of the air lift bioreactor was capable to develop an anoxic zone and remove nitrogen under continuous aeration. The internal tube as a physical separation provides anoxic and aerobic zones to grow various species of nitrifying and denitrifying bacteria in the bioreactor.

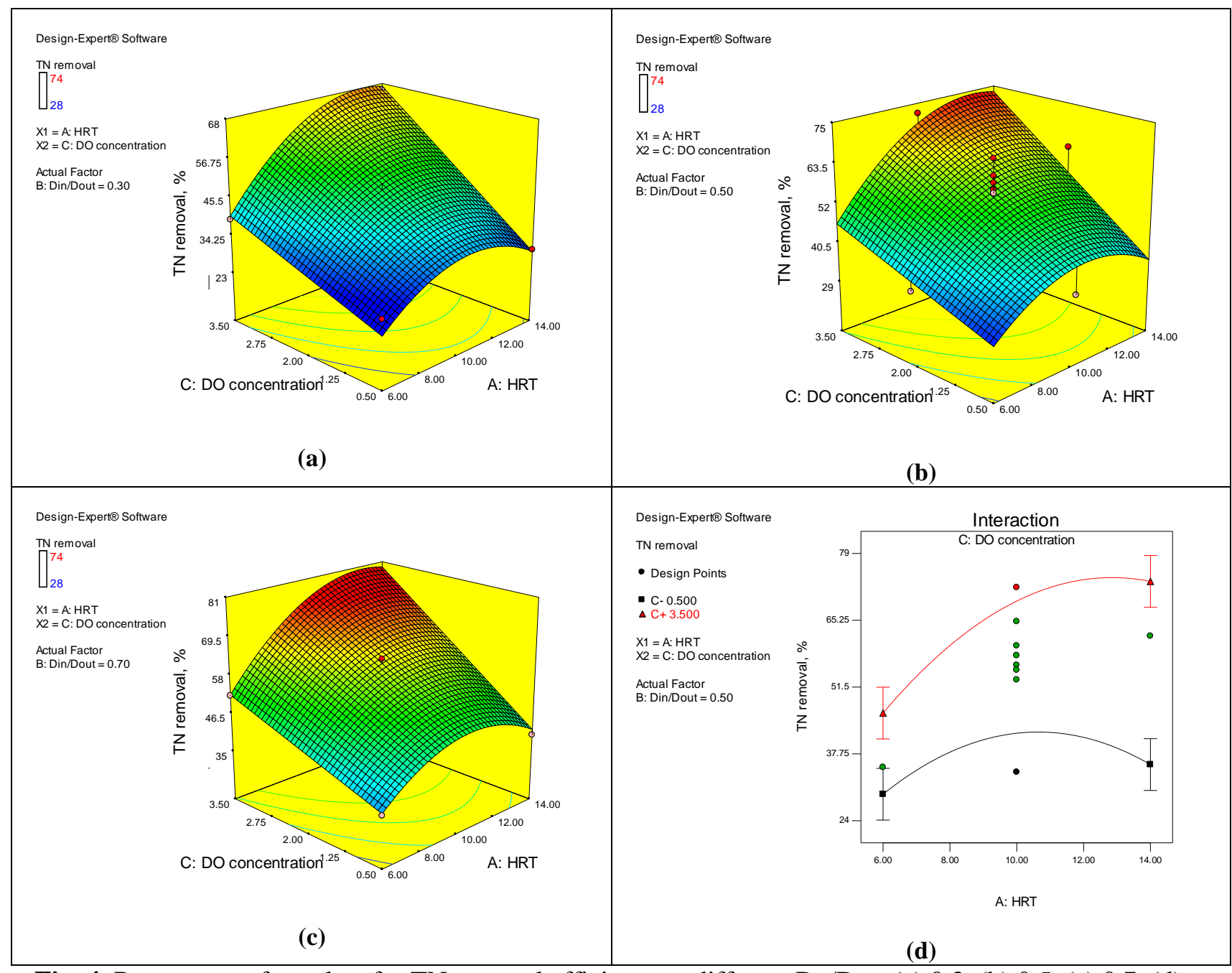

Fig. 4. Response surface plots for $T N$ removal efficiency at different $D_{\text {in }} / D_{\text {out }}$ : (a) 0.3, (b) 0.5, (c) 0.7. (d) Interactive effect of HRT and DO concentration on the response at $\mathrm{D}_{\mathrm{in}} / \mathrm{D}_{\text {out }}$ of 0.5 . 


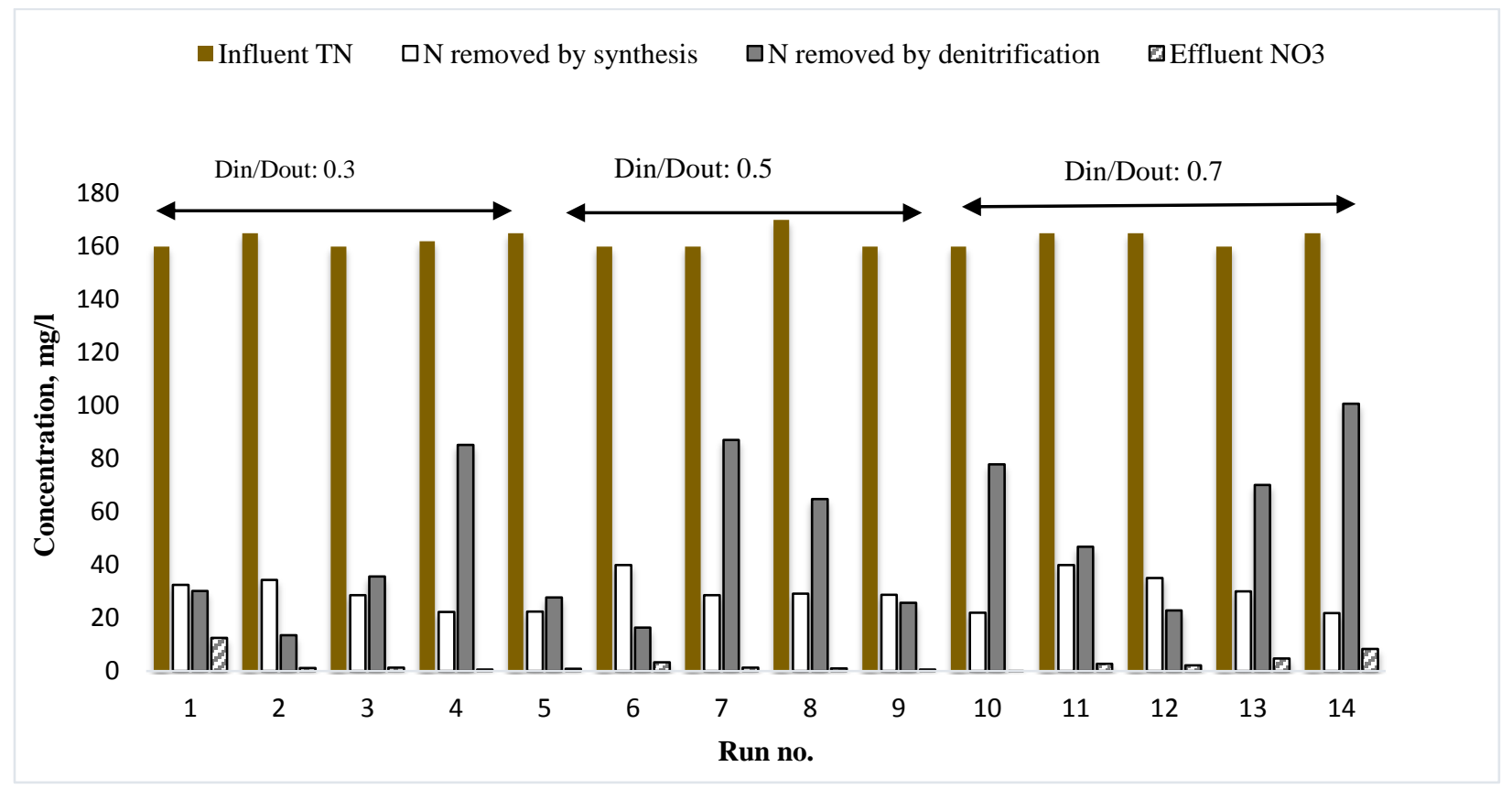

Fig. 5. The fate of nitrogen contents through different reactions at different operating conditions.

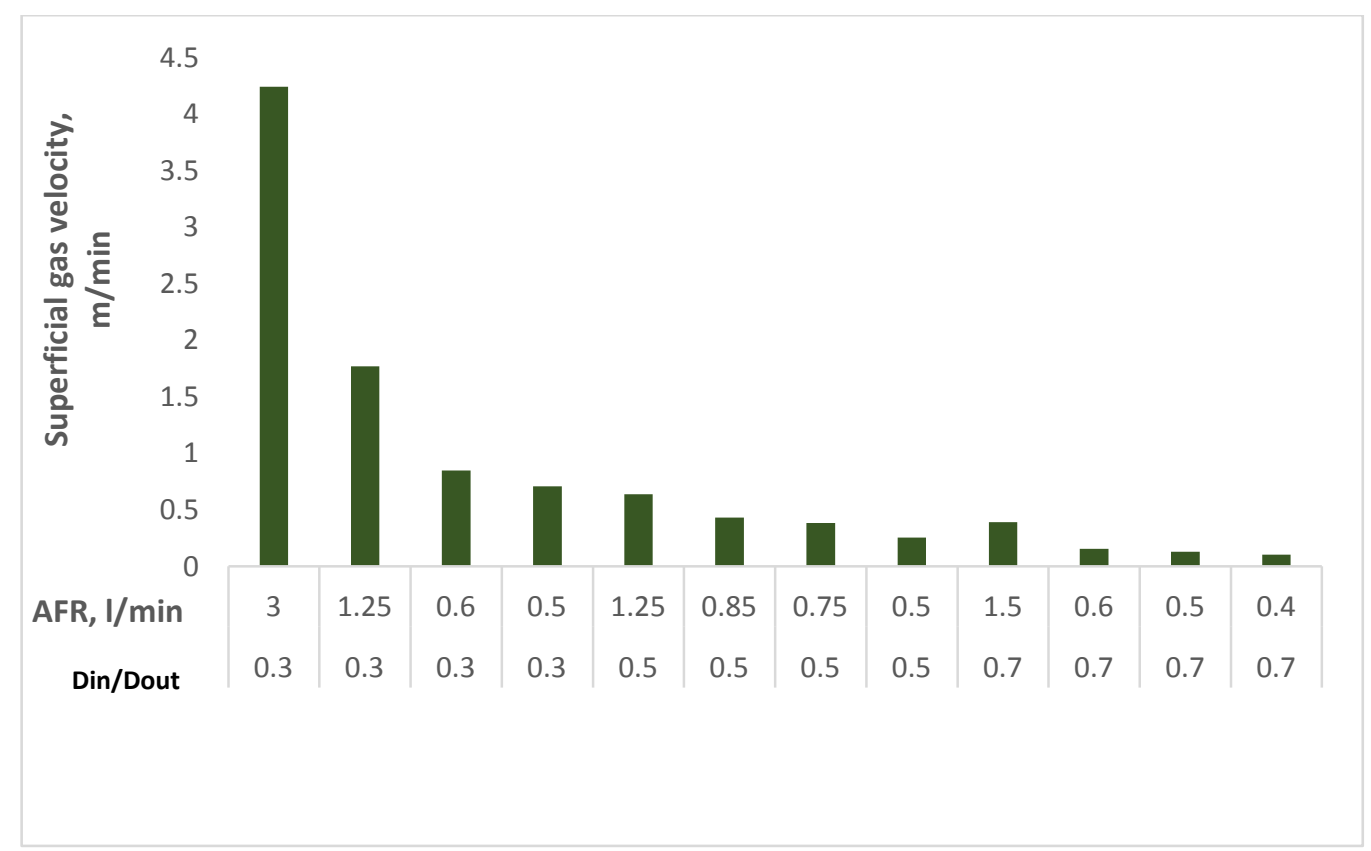

Fig. 6. Superficial gas velocity as a function of air flow rate (AFR) and $D_{\text {in }} / D_{\text {out }}$. 


\subsubsection{TP removal}

Biological removal of phosphorus is a process which requires two conditions with different oxidation potentials, anaerobic $(\leq-100 \mathrm{mv})$ and aerobic $(\geq+100 \mathrm{mv})$ zones. Special species of bacteria are responsible for removing phosphorus compounds (phosphorus accumulating organisms (PAOs)) which accumulates phosphorus in the aerobic condition only if it already passed anaerobic zones with enough carbon source [39]. Developing anaerobic and aerobic zones in a single bioreactor has been noticed by researchers recently. Therefore, in this study, TP removal efficiency was measured as a response.

A reduced quadratic model describes the data obtained for TP removal efficiency as a function of the variables. From Table 4, A, B, C, were significant model terms with positive direct effects and $\mathrm{AB}$ and $\mathrm{A}^{2}$ had negative effects. The VIF value was 1 for $\mathrm{A}, \mathrm{B}, \mathrm{C}$, and $\mathrm{AB}$ and for the other remaining model terms was 1.56 , verifying the independency of the attained model terms.

Figs. 7a, $b$ and c present the variation of the response as a function of HRT and $D_{\text {in }} / D_{\text {out }}$ at DO concentrations of $0.5,2$, and $3.5 \mathrm{mg} / \mathrm{l}$, respectively. From the figure, TP removal shows an identical trend at different DO concentrations by varying HRT and $\mathrm{D}_{\text {in }} / \mathrm{D}_{\text {out }}$. At DO concentration of $0.5 \mathrm{mg} / \mathrm{l}$, the response was increased by increasing $\mathrm{HRT}$ and $\mathrm{D}_{\text {in }} / \mathrm{D}_{\text {out }}$, denoting the restriction of aerobic zone. Minimum TP removal efficiency was obtained under a condition with the lowest $\mathrm{D}_{\mathrm{in}} / \mathrm{D}_{\text {out }}$ and HRT at different DO concentrations (30-35\%). At DO concentration of $3.5 \mathrm{mg} / \mathrm{l}$, high value of air flow rate (18 1 air/ 1 reactor.h) is needed, generating high superficial gas velocity $(4.2 \mathrm{~m} / \mathrm{min})$ and turbulent flow in the bioreactor. The turbulent flow in the bioreactor led to a deterioration of anaerobic zone at the beginning of operating run. In essence, the circulation between inside and outside of the internal column occurred before developing anaerobic zone 
which caused an upset in TP removal process. At a DO concentration of $0.5 \mathrm{mg} / \mathrm{l}$, the anaerobic zone was developed properly as a result of low air flow rate. In this condition, the lack of required oxidation potential is a reason to obtain the minimum TP removal.

The effect of HRT at the lowest $\mathrm{D}_{\text {in }} / \mathrm{D}_{\text {out }}$ was more significant compared to the higher $\mathrm{D}_{\mathrm{in}} / \mathrm{D}_{\text {out }}$ at all DO concentrations. For each DO concentration level, there is a different explanation. At DO concentration of $0.5 \mathrm{mg} / \mathrm{l}$ and $\mathrm{D}_{\text {in }} / \mathrm{D}_{\text {out }}$ of 0.3 , the F/M ratio is decreased with increasing HRT which led to more efficiency of aerobic zone to absorb TP [40]. At the DO concentration of 3.5 $\mathrm{mg} / \mathrm{l}$ and $\mathrm{D}_{\text {in }} / \mathrm{D}_{\text {out }}$ of 0.3 , the required air flow rate is decreased with increasing HRT, providing more anaerobic zone due to delaying the circulation in the bioreactor (Table 3). The effect of HRT was clearly decreased with increasing diameter of the internal tube.

Similar to HRT, with increasing $D_{\text {in }} / \mathrm{D}_{\text {out }}$, the contribution of aerobic zone was increased which triggered more oxidation time and eventually an enhancement in TP removal efficiency. The effect of $D_{\text {in }} / D_{\text {out }}$ was decreased gradually as HRT was increased. Fig. $7 d$ shows the interactive effect of HRT and $D_{\text {in }} / D_{\text {out }}$ on the response at DO concentration of $2 \mathrm{mg} / \mathrm{l}$. As can be seen in the Fig., $A B$ interaction shows a negative effect; more decreasing effect of $A$ at higher $D_{\text {in }} / D_{\text {out. }}$ It is noted that the increasing effect of $\mathrm{A}$ is more significant. 


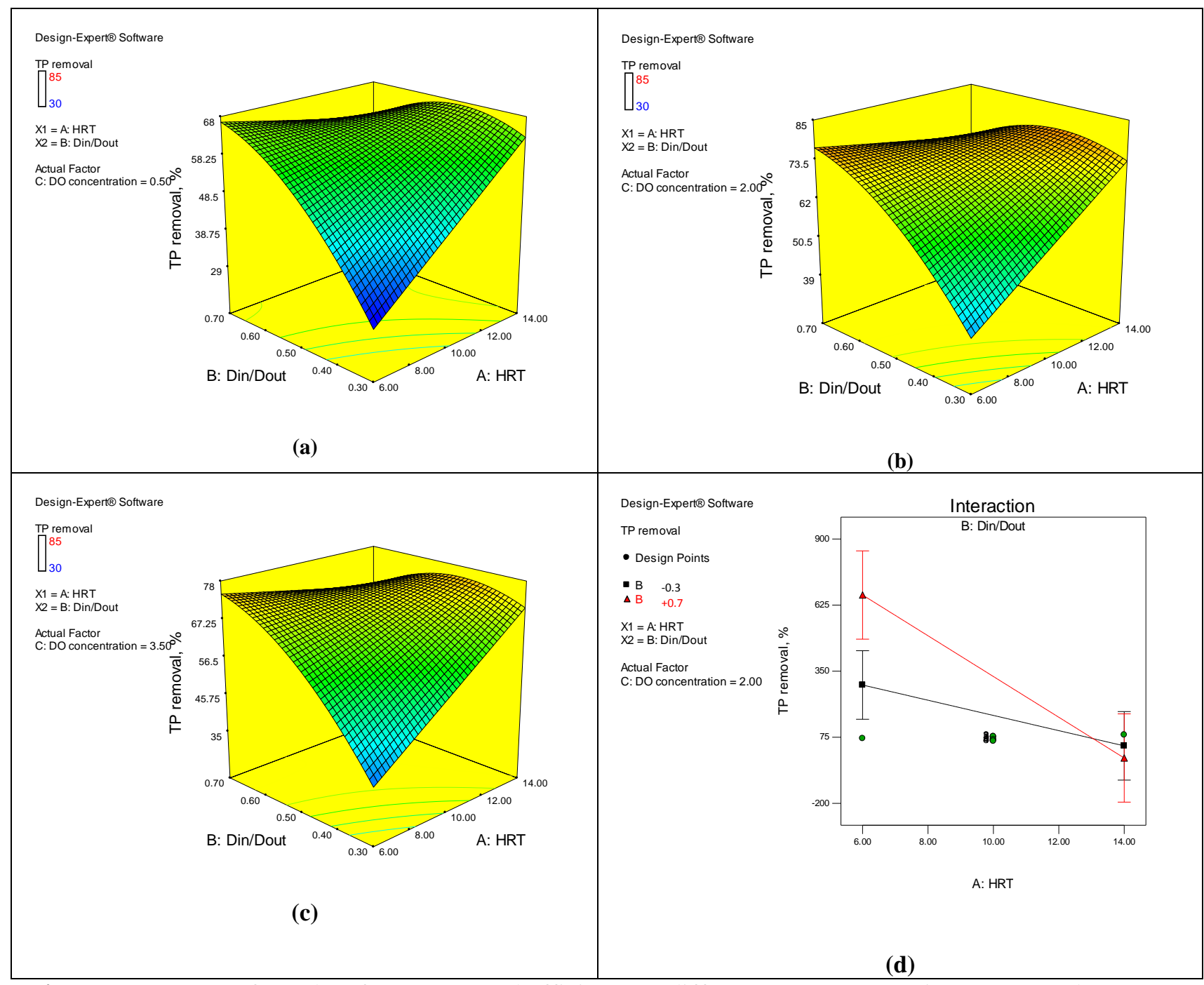

Fig. 7. Response surface plots for TP removal efficiency at different DO concentrations: (a) 0.5, (b) 2, (c) $3.5 \mathrm{mg} / \mathrm{l}$. (d) Interactive effect of HRT and $\mathrm{D}_{\mathrm{in}} / \mathrm{D}_{\text {out }}$ on the response at middle level of DO concentration $(2 \mathrm{mg} / \mathrm{l})$.

\subsubsection{Effluent turbidity}

The effluent clarification is of high importance to evaluate treatment performance in the bioreactor which is described by the effluent turbidity in this section. From Table 4, A, B, C, AC, $\mathrm{BC}$, and $\mathrm{B}^{2}$ are significant model terms to describe effluent turbidity. Also, VIF value for all the model terms is one, indicating the reliability of the obtained equation to describe the response as 
a function of the variables. As seen in the equation (Table 4), term $\mathrm{C}$ showed the most negative direct effect on the response relative to the other variables with a coefficient -9.5 .

Figs. 8a, b, and c show the variation trend of the effluent turbidity as a function of HRT and $\mathrm{D}_{\text {in }} / \mathrm{D}_{\text {out }}$ at the different levels of DO concentration. The range of the effluent turbidity at different operating conditions applied was 10-42 NTU. From the figures, DO concentration showed a decreasing effect on the response. As it is found from the literature, DO concentration is one of the important parameters to control the effluent turbidity [41]. As a fact, higher DO concentration favored condition forming more stable and dense flocs.

Fig. 8d demonstrates interactive effect of $\mathrm{AC}$ on the response. Term A showed a decreasing effect at the lowest $\mathrm{C}(0.5 \mathrm{mg} / \mathrm{l})$ while almost no effect at the highest $\mathrm{C}(3.5 \mathrm{mg} / \mathrm{l})$. At the condition with the highest F/M ratio (HRT of $6 \mathrm{~h}$ and $\mathrm{D}_{\text {in }} / \mathrm{D}_{\text {out }}$ of 0.3 ), the effluent turbidity is relatively high $(41,30$, and 12 at DO concentration of $0.5,2$, and $3.5 \mathrm{mg} / \mathrm{l}$, respectively). As a conclusion larger $\mathrm{D}_{\text {in }} / \mathrm{D}_{\text {out }}$ led to higher effluent quality. 


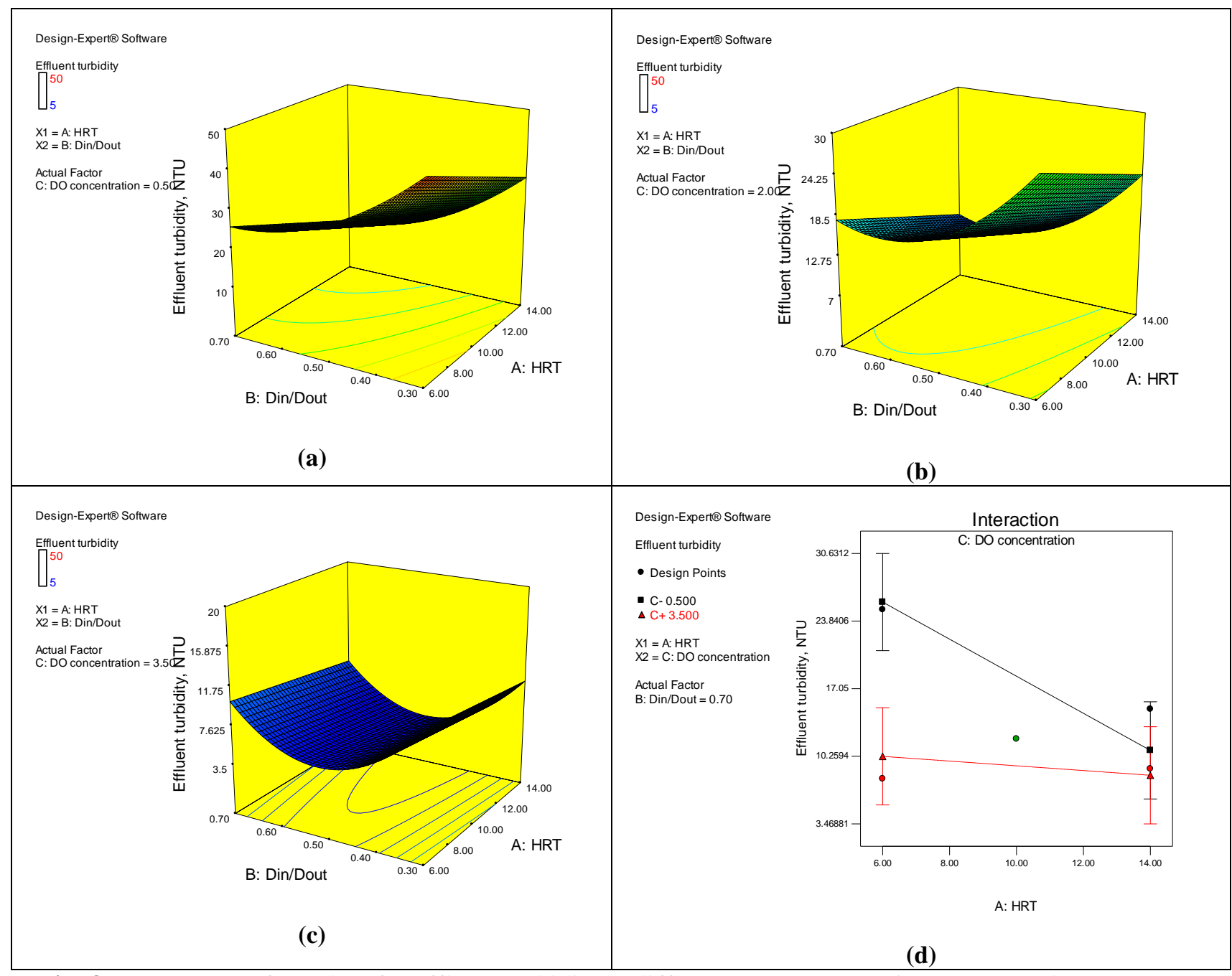

Fig. 8. Response surface plots for effluent turbidity at different DO concentrations: (a) 0.5, (b) 2, (c) 3.5 $\mathrm{mg} / \mathrm{l}$. (d) Interactive effect of HRT and DO concentration on the response at middle level of $\mathrm{D}_{\text {in }} / \mathrm{D}_{\text {out }}$ $(0.5)$.

\subsection{Process optimization and verification}

Figs. 9a, b, and c show the graphical optimization for the system at DO concentrations of $0.5,2$, and $3.5 \mathrm{mg} / \mathrm{l}$, respectively. It displays the areas of feasible response values (shaded portion) in the factors space. The optimum regions were recognized in the figures based on five critical responses (sCOD removal, $\mathrm{TN}$ removal, effluent $\mathrm{NO}_{3}{ }^{-}$concentration, $\mathrm{TP}$ removal and effluent turbidity). From the figures, the optimum region is not provided at DO concentration of 0.5 and 2 $\mathrm{mg} / \mathrm{l}$, implying on limitation of DO concentration in the bioreactor. The shaded area on the 
overlay plot in the figure $8 \mathrm{c}$ is the region that meets the proposed criteria presented in Table 5. The optimum region appeared at DO concentration of $3.5 \mathrm{mg} / \mathrm{l}$ due to a good balance between the processes required for the simultaneous carbon and nutrients removal. As demonstrated in the figure (8c), the optimum region is covered by HRT $10-14 \mathrm{~h}$ and $\mathrm{D}_{\mathrm{in}} / \mathrm{D}_{\text {out }}$ at the range of 0.4-0.6.

To examine the applied models for describing the data and also the predicted optimum region, the bioreactor was operated at a selected condition within the optimum region. The condition was HRT, $\mathrm{D}_{\mathrm{in}} / \mathrm{D}_{\text {out }}$, DO concentration of $12 \mathrm{~h}, 0.5$, and $3.5 \mathrm{mg} / \mathrm{l}$, respectively. In order to verify the models, five quality parameters were measured and compared to the predicted values from the model as shown in Table 6. From the Table, there is no significant difference between the experimental data and the model predictions in terms of sCOD removal, TN removal, TP removal, effluent $\mathrm{NO}_{3}{ }^{-}$concentration, and effluent turbidity. Therefore, it can be concluded that the presented models are reliable to model the experimental data in the design space.

Table 5. The optimization criteria for the responses studied.

\begin{tabular}{lll}
\hline Response & Limit & Unit \\
\hline sCOD removal & $\geq 98$ & $\%$ \\
TN removal & $\geq 70$ & $\%$ \\
Effluent $\mathrm{NO}_{3}{ }^{-}$ & $\leq 1$ & $\mathrm{mg} / 1$ \\
TP removal & $\geq 70$ & $\%$ \\
Effluent turbidity & $\leq 5$ & $\mathrm{NTU}$ \\
\hline
\end{tabular}

Table 6. Verification experiments at optimum conditions.

\begin{tabular}{|c|c|c|c|c|c|c|}
\hline \multirow[t]{2}{*}{ Conditions } & & \multicolumn{5}{|l|}{ Response } \\
\hline & & $\begin{array}{l}\text { TCOD } \\
\text { removal, } \\
\%\end{array}$ & $\begin{array}{l}\text { TN removal, } \\
\%\end{array}$ & $\begin{array}{l}\text { TP removal, } \\
\%\end{array}$ & $\begin{array}{l}\text { Effluent } \\
\text { turbidity, NTU }\end{array}$ & $\begin{array}{l}\text { Effluent } \\
\text { nitrate, } \\
\text { mg/l }\end{array}$ \\
\hline $\mathrm{HRT}=12 \mathrm{~h}$ & Experimental values & 100 & 72 & 73.48 & 4 & 1.1 \\
\hline Internal diameter $=5 \mathrm{~cm}$ & Model values & 100 & 73.56 & 71.58 & 4.02 & 1.47 \\
\hline $\begin{array}{l}\text { DO concentration }=3.5 \\
\mathrm{mg} / \mathrm{l}\end{array}$ & Standard deviation & 0 & 1.11 & 1.34 & 0.014 & 0.26 \\
\hline
\end{tabular}




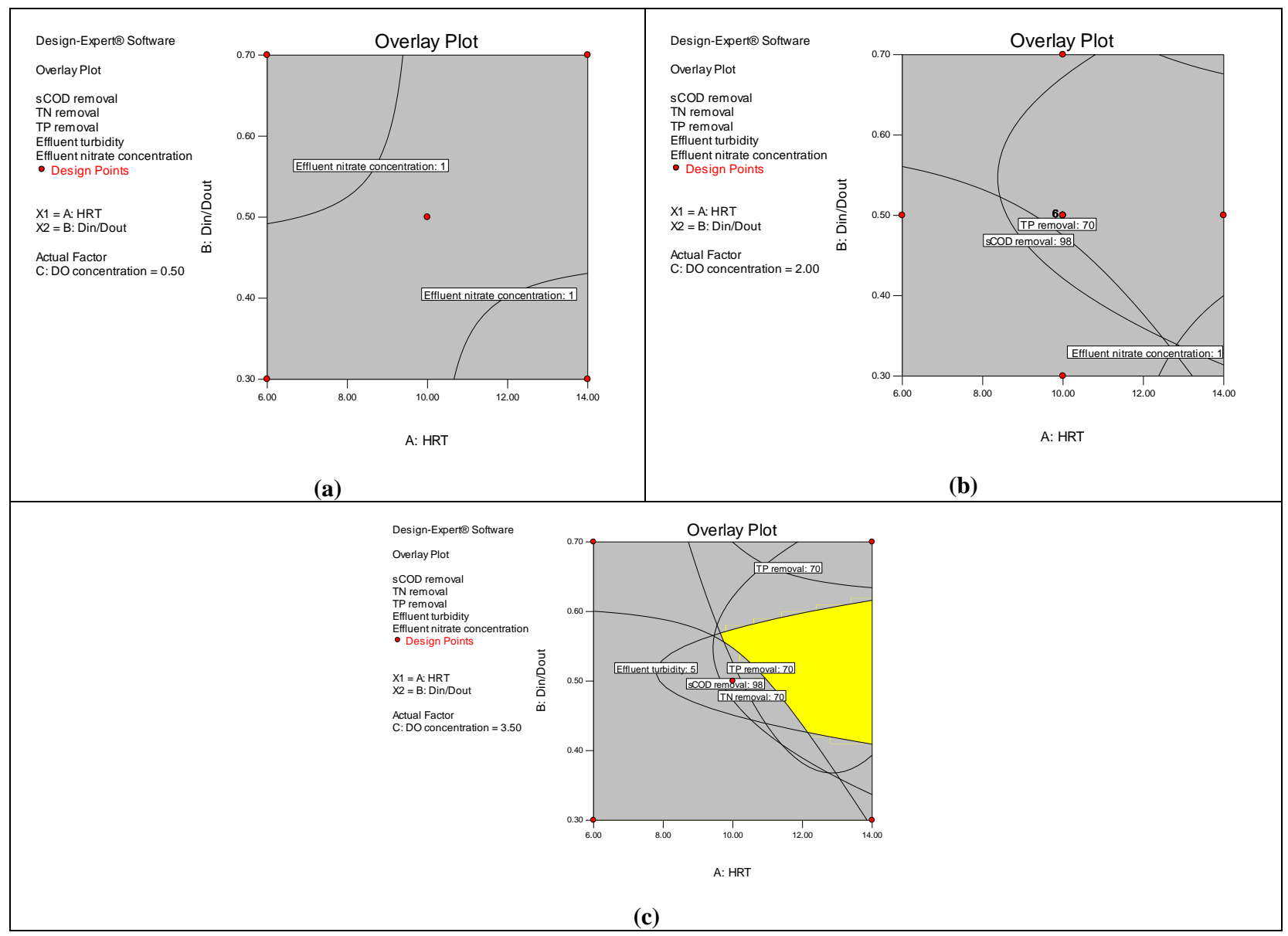

Fig. 9. Overlay plot for the optimal region at different DO concentrations: (a) 0.5 , (b) 2.5 , (c) $3.5 \mathrm{mg} / \mathrm{l}$.

\subsection{Long term performance in terms of TP removal}

In order to assess TP removal process for long time operation, the bioreactor was operated at the optimum condition (HRT, $\mathrm{D}_{\text {in }} / \mathrm{D}_{\text {out }}$ and DO concentration of $12 \mathrm{~h}, 0.5$ and $3.5 \mathrm{mg} / \mathrm{l}$, respectively) for a 60-cycle run (30 days). TP removal and oxidation reduction potential (ORP) were monitored during the operation. The ORP value before circulation flow in the downcomer stream was measured as anaerobic zone (table 7). Also, the ORP values at the top and bottom of the bioreactor (at the end of operating run) were considered as aerobic and anoxic zones, respectively (table 7). The measured values for ORP clearly indicate the occurrence of different redox zones needed for good nitrogen and phosphorus removal. 
The trends of the effluent TP concentration and TP removal efficiency are depicted in Fig. 10. From the figure, at the first cycle which presents the maximum TP removal capacity, the effluent TP concentration and TP removal efficiency were found to be around $37 \mathrm{mg} / \mathrm{l}$ and $70 \%$, respectively. In general, from cycle 1 to 30 , an instability in TP removal efficiency was observed, from cycle 30 onwards the system showed a stable removal efficiency around $60 \%$. During the run, the surplus sludge was discharged, with an SRT maintained at about 40 days throughout the experiments. As a significant achievement from this particular study, this single bioreactor is capable to remove about $60 \%$ (30 mg/l) of influent $\mathrm{P}_{-} \mathrm{PO}_{4}{ }^{3-}$ concentration over longterm operation due to providing a proper balance between anaerobic and aerobic zones. Over the first 15 days (30 cycles), two increasing steps were observed, indicating the accumulation of phosphate in $\mathrm{PAO}_{\mathrm{s}}$ and imbalance between releasing and absorbing processes of $\mathrm{P}-\mathrm{PO}_{4}{ }^{3-}[42]$.

Table 7. ORP values at different ports of the reactor in the optimum condition (HRT: $\left.12 \mathrm{~h}, \mathrm{D}_{\text {in }} / \mathrm{D}_{\text {out }}: 0.5, \mathrm{DO}: 3.5 \mathrm{mg} / \mathrm{l}\right)$

\begin{tabular}{llll}
\hline & $\begin{array}{l}\text { At down comer before } \\
\text { circulation as } \\
\text { "Anaerobic phase" }\end{array}$ & $\begin{array}{l}\text { At the end of each cycle before } \\
\text { settling at reactor bottom as } \\
\text { "Anoxic phase" }\end{array}$ & $\begin{array}{l}\text { At the end of each cycle } \\
\text { before settling at reactor top } \\
\text { as "Aerobic phase" }\end{array}$ \\
\hline $\begin{array}{l}\text { Optimum } \\
\text { condition }\end{array}$ & $-370 \mathrm{mv}$ & +80 & +240 \\
\hline Literature [43] & $\leq-100 \mathrm{mv}$ & $\pm 50-100 \mathrm{mV}$ & $\geq+100 \mathrm{mv}$ \\
\hline
\end{tabular}




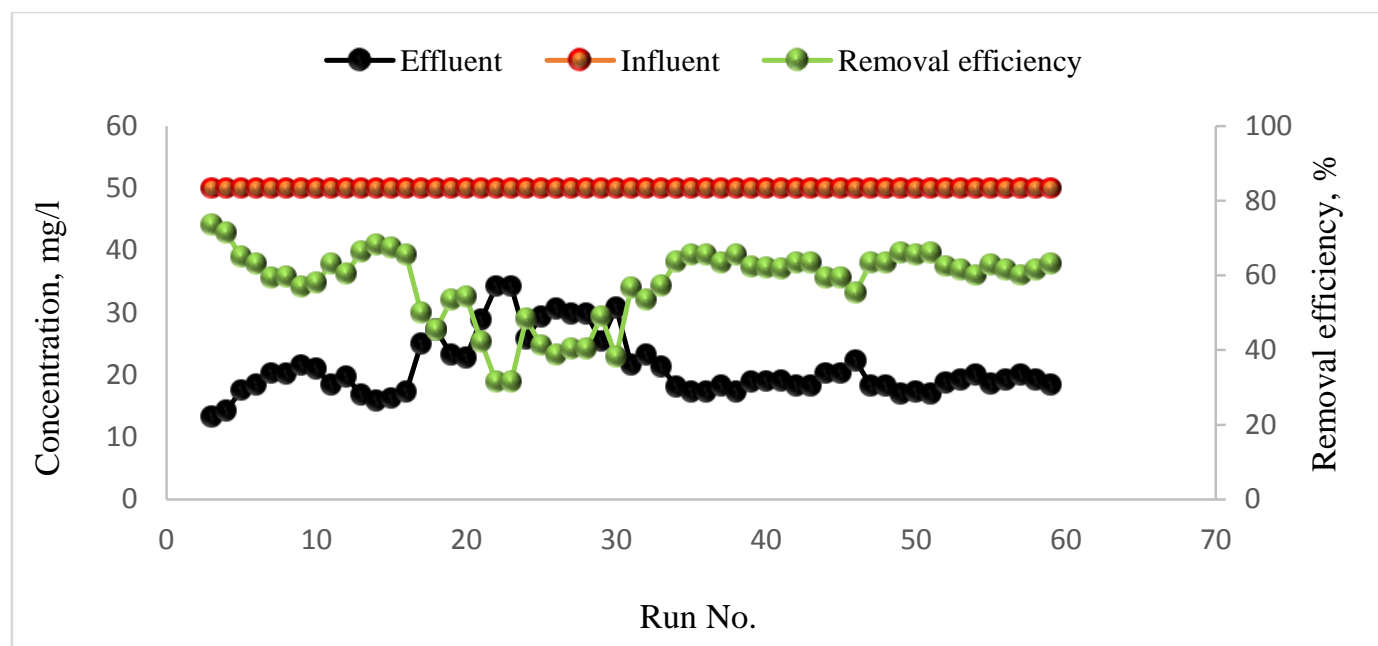

Fig. 10. Variation trend of the effluent TP concentration during 30 days (60-cycle run) continuous operation at the optimum condition.

\subsection{Effect of $\mathrm{COD} / \mathrm{N}$ ratio}

In order to investigate the effect of $\mathrm{COD} / \mathrm{N}$ ratio on the process performance, the $\mathrm{CFIDAB}$ was operated at 9 selected runs with two different ratios of $\mathrm{COD} / \mathrm{N}$ (6.26 and 16.6). The actual data of 5 responses at the two levels of $\mathrm{COD} / \mathrm{N}$ ratio is presented in Table 8 . The $\mathrm{COD} / \mathrm{N}$ ratio showed no significant effect on COD and TP removal efficiency and effluent $\mathrm{NO}_{3}{ }^{-}$concentration at different experimental conditions, however, $\mathrm{COD} / \mathrm{N}$ ratio showed a positive effect on removing nitrogen at particular operating conditions. It is clearly observed that $\mathrm{TN}$ removal was independent to $\mathrm{COD} / \mathrm{N}$ ratio at $\mathrm{DO}$ concentration of $0.5 \mathrm{mg} / \mathrm{l}$, indicating a limited nitrification process in the low oxidation potential. At DO concentrations of 2 and $3.5 \mathrm{mg} / \mathrm{l}$, the TN removal efficiency was increased with decreasing $\mathrm{COD} / \mathrm{N}$ ratio which confirms the high capacity of this system for nitrogen removal. 
Table 8. Process performance at different COD/N ratios.

\begin{tabular}{|c|c|c|c|c|c|c|c|c|c|c|c|}
\hline \multicolumn{4}{|c|}{ Variables } & \multicolumn{4}{|c|}{$\begin{array}{c}\text { Responses } \\
(\mathrm{COD} / \mathrm{N}: 6.2)\end{array}$} & \multicolumn{4}{|c|}{$\begin{array}{c}\text { Responses } \\
\text { (COD/N: 16.6) }\end{array}$} \\
\hline Run & $\begin{array}{c}\text { Factor1 } \\
\text { A:Din/Dout }\end{array}$ & $\begin{array}{c}\text { Factor2 } \\
\text { B:HRT } \\
\text { h }\end{array}$ & $\begin{array}{c}\text { Factor3 } \\
\text { C: DO } \\
\text { mg/l }\end{array}$ & $\begin{array}{c}\text { SCOD } \\
\text { removal, } \\
\%\end{array}$ & $\begin{array}{c}\text { TN } \\
\text { removed, } \\
\text { mg/l }\end{array}$ & $\begin{array}{c}\text { TP } \\
\text { removal, } \\
\%\end{array}$ & $\begin{array}{c}\text { Effluent } \\
\text { N-NO } \\
\text { mg/l }\end{array}$ & $\begin{array}{c}\text { SCOD } \\
\text { removal, } \\
\%\end{array}$ & $\begin{array}{c}\text { TN } \\
\text { removed, } \\
\text { mg/l }\end{array}$ & $\begin{array}{c}\text { TP } \\
\text { removal, } \\
\%\end{array}$ & $\begin{array}{c}\text { Effluent } \\
\mathrm{N}^{-N O_{3}}, \\
\text { mg/l }\end{array}$ \\
\hline 1 & 0.3 & 6 & 3.5 & 91 & 47.61 & 37 & 12.49 & 91 & 36.11 & 40 & 12.75 \\
\hline 2 & 0.3 & 6 & 0.5 & 84 & 34.19 & 30 & 1.2 & 83 & 31.95 & 31 & 0.54 \\
\hline 3 & 0.3 & 14 & 3.5 & 97 & 100.5 & 70 & 0.5 & 96 & 53.33 & 73 & 0.79 \\
\hline 4 & 0.3 & 14 & 0.5 & 93 & 40 & 61 & 0.5 & 93 & 39.9 & 63 & 0.3 \\
\hline 5 & 0.5 & 10 & 2 & 100 & 54 & 55 & 0.95 & 100 & 57 & 55 & 1 \\
\hline 6 & 0.7 & 6 & 3.5 & 92 & 88 & 71 & 3.43 & 94 & 58 & 74 & 3.2 \\
\hline 7 & 0.7 & 6 & 0.5 & 86 & 57.87 & 57 & 2.13 & 87 & 55.8 & 58 & 1.8 \\
\hline 8 & 0.7 & 14 & 3.5 & 99 & 122 & 62 & 5.4 & 99 & 58 & 65 & 5.2 \\
\hline 9 & 0.7 & 14 & 0.5 & 96 & 66 & 60 & 3 & 96 & 58.4 & 62 & 2.9 \\
\hline
\end{tabular}

\subsection{A comparative review on the single bioreactors}

Table 9 compares the performance of this innovative system with other bioreactors applied for the simultaneous nutrients removal $[13,14,23,25,44-48]$. It is clearly found from Table 9 , single bioreactors with CFID regime shows more capability to remove CNP from wastewater relative to the other proposed single bioreactors. As mentioned earlier, the CFID regime has dual benefits of both batch and continuous regimes. Airlift intermittent circulation membrane bioreactor has also shown good performance removing 72 and $10.9 \mathrm{mg} / \mathrm{l}$ of TN and TP, respectively, considering that the feed was glucose with $\mathrm{COD} / \mathrm{N}$ ratio of 7.4 and HRT has been $22 \mathrm{~h}$. It is noted that HRT values for the bioreactors with CFID regime are in the range of 6-12h. It must be mentioned that in the bioreactors no. 6 and 7 (Table 9), aerobic, anoxic, and anaerobic zones are provided by adjusting aeration time demonstrating more removal efficiencies in terms of TN (180 and $110 \mathrm{mg} / \mathrm{l}$ of TN) compared to other CFID bioreactors. Granular sludge in CFID bioreactor (no. 8) shows an excellent performance in nitrogen removal $(135 \mathrm{mg} / \mathrm{l})$ comparable with the intermittent aeration technique, however, it is not capable to provide a good anaerobic zone and phosphorus removal. 
Other CFID bioreactors (no. 9 and 10) reduce carbon and nutrients content via physical separation technique. At CFID bioreactor with a movable aerator (no. 9) 75 and $12 \mathrm{mg} / \mathrm{l}$ of nitrogen and phosphorus from soft drink wastewater were removed, respectively, at HRT of $8 \mathrm{~h}$ and $\mathrm{COD} / \mathrm{N}$ ratio of 10 . While, CFIDAB is capable to eliminate $116 \mathrm{mg} / \mathrm{l}$ of $\mathrm{TN}$ and $30 \mathrm{mg} / \mathrm{l}$ of TP from soft drink wastewater with COD/N ratio of 6.2 at HRT of $12 \mathrm{~h}$. This comparison clearly proved that this innovative system can be considered as a high rate single bioreactor for the simultaneous CNP removal from wastewater with high NP contents which reduces the required volume, energy consumption, and complication of operation.

Table 9. Performance of different single bioreactors for simultaneous CNP removal.

\begin{tabular}{|c|c|c|c|c|c|c|c|c|c|}
\hline No & System & Feed & $\begin{array}{c}\mathrm{COD} / \mathrm{N} \\
\text { ratio }\end{array}$ & $\begin{array}{c}\text { Influent } \\
\text { TN, } \\
\text { mg/l }\end{array}$ & $\begin{array}{c}\text { Influent } \\
\text { TP, } \\
\text { mg/l }\end{array}$ & $\begin{array}{c}\text { TN } \\
\text { removed, } \\
\text { mg/l }\end{array}$ & $\begin{array}{c}\mathrm{TP} \\
\text { removed, } \\
\mathrm{mg} / \mathrm{l}\end{array}$ & $\begin{array}{c}\text { HRT } \\
\text { h } \\
\end{array}$ & Ref. \\
\hline 1 & $\begin{array}{l}\text { Vertical submerged membrane } \\
\text { bioreactor (VSMBR) }\end{array}$ & Glucose & 10 & 30 & 6 & 27 & 5.95 & $\begin{array}{l}\text { Aerobic }=2 \\
\text { Anoxic }=4\end{array}$ & [31] \\
\hline 2 & $\begin{array}{l}\text { Continuous anaerobic-aerobic- } \\
\text { anoxic process (AOA) }\end{array}$ & Domestic & 6 & 50 & 3.8 & 45 & 3.79 & 8 & [32] \\
\hline 3 & $\begin{array}{l}\text { Combo system of fluidized bed } \\
\text { reactor-membrane } \\
\text { bioreactor (FBR-MBR) }\end{array}$ & Sewage & 4.1 & 60 & 10 & 59 & 9.1 & 6 & [33] \\
\hline 4 & $\begin{array}{l}\text { Airlift loop reactor under a limited } \\
\text { filamentous bulking state }\end{array}$ & Acetate & 7.5 & 40 & 7 & 37 & 6.6 & 11 & [7] \\
\hline 5 & $\begin{array}{l}\text { Airlift intermittent circulation } \\
\text { membrane bioreactor }\end{array}$ & Glucose & 7.4 & 87 & 12.1 & 72 & 10.9 & 22 & {$[8]$} \\
\hline 6 & $\begin{array}{l}\text { Single up-flow aerobic/anoxic } \\
\text { sludge bed (UAASB) bioreactor } \\
\text { with CFID regime }\end{array}$ & $\begin{array}{c}\text { Industrial } \\
\text { estate }\end{array}$ & 5 & 210 & 50 & 180 & 16 & 12 & [17] \\
\hline 7 & $\begin{array}{l}\text { Single ultrasound augmented up- } \\
\text { flow anaerobic/aerobic/anoxic } \\
\text { bioreactor with CFID regime }\end{array}$ & $\begin{array}{c}\text { Milk } \\
\text { processing }\end{array}$ & 6 & 170 & 50 & 110 & 25 & 6 & [19] \\
\hline 8 & $\begin{array}{l}\text { Aerobic granular sludge in a single } \\
\text { bioreactor with CFID regime }\end{array}$ & $\begin{array}{c}\text { Milk } \\
\text { processing }\end{array}$ & 6 & 170 & 50 & 135 & 3 & 8 & [34] \\
\hline 9 & $\begin{array}{l}\text { Single up flow aerobic/anoxic } \\
\text { bioreactor with CFID regime and a } \\
\text { movable aerator }\end{array}$ & Soft drink & 10 & 125 & 40 & 75 & 12 & 8 & [35] \\
\hline 10 & $\begin{array}{l}\text { CFIDAB } \\
\text { (optimum condition) }\end{array}$ & Soft drink & 6.2 & 160 & 50 & 116 & 30 & 12 & $\begin{array}{l}\text { This } \\
\text { study }\end{array}$ \\
\hline
\end{tabular}




\section{Conclusion}

In this study, an innovative continuous feed and intermittent discharge air lift bioreactor (CFIDAB), having different reaction zones, was successfully operated to remove carbon and nutrients simultaneously from soft drink wastewater. The main conclusions are:

1) Anaerobic, anoxic, and aerobic zones with three different ranges of ORP could be successfully established in the single CFIDAB with continuous aeration.

2) Superficial gas velocity is a key control factor to achieve optimum operating condition.

3) The optimum region for the variables was determined to be HRT of $10-14 \mathrm{~h}, \mathrm{D}_{\text {in }} / \mathrm{D}_{\text {out }}$ of 0.4-0.6, and DO concentration of $3.5 \mathrm{mg} / \mathrm{l}$.

4) The performance of CFIDAB was stable over long-term operation, therefore CFIDAB is a promising design with reliable performance to be implemented in industrial scale.

\section{Acknowledgement}

The authors would like to acknowledge Iran National Science Foundation (INSF) for the full financial support provided for this research work. 


\section{References:}

[1] I. Hussain, L. Raschid, M.A. Hanjra, F. Marikar, W. Van Der Hoek, Wastewater Use in Agriculture: Review of Impacts and Methodological Issues in Valuing Impacts: with an Extended List of Bibliographical References, Iwmi, 2002.

[2] N. Gottschall, C. Boutin, A. Crolla, C. Kinsley, P. Champagne, The role of plants in the removal of nutrients at a constructed wetland treating agricultural (dairy) wastewater, Ontario, Canada, Ecol. Eng. 29 (2007) 154-163.

[3] R. Parry, Agricultural phosphorus and water quality: A US Environmental Protection Agency perspective, J. Environ. Qual. 27 (1998) 258-261.

[4] K. Yetilmezsoy, Z. Sapci-Zengin, Recovery of ammonium nitrogen from the effluent of UASB treating poultry manure wastewater by MAP precipitation as a slow release fertilizer, J. Hazard. Mater. 166 (2009) 260-269.

[5] M.I. Badawy, R.A. Wahaab, A. El-Kalliny, Fenton-biological treatment processes for the removal of some pharmaceuticals from industrial wastewater, J. Hazard. Mater. 167 (2009) 567-574.

[6] S. Yang, F. Yang, Z. Fu, T. Wang, R. Lei, Simultaneous nitrogen and phosphorus removal by a novel sequencing batch moving bed membrane bioreactor for wastewater treatment, J. Hazard. Mater. 175 (2010) 551-557.

[7] Y.J. Chan, M.F. Chong, C.L. Law, D. Hassell, A review on anaerobic-aerobic treatment of industrial and municipal wastewater, Chem. Eng. J. 155 (2009) 1-18.

[8] B. Farizoglu, B. Keskinler, E. Yildiz, A. Nuhoglu, Simultaneous removal of C, N, P from cheese whey by jet loop membrane bioreactor (JLMBR), J. Hazard. Mater. 146 (2007) 399-407.

[9] T. Hano, M. Matsumoto, K. Kuribayashi, Y. Hatate, Biological nitrogen removal in a bubble column with a draught tube, Chem. Eng. Sci. 47 (1992) 3737-3744.

[10] W.A.J. van Benthum, J.H.A. van den Hoogen, R.G.J.M. van der Lans, M.C.M. van Loosdrecht, J.J. Heijnen, The biofilm airlift suspension extension reactor. Part I: Design and two-phase hydrodynamics, Chem. Eng. Sci. 54 (1999) 1909-1924.

[11] L. Garbossa, K. Lapa, M. Zaiat, E. Foresti, Development and evaluation of a radial anaerobic/aerobic reactor treating organic matter and nitrogen in sewage, Braz. J. Chem. Eng. 22 (2005) 511-519.

[12] Z. Yang, S. Zhou, The biological treatment of landfill leachate using a simultaneous aerobic and anaerobic (SAA) bio-reactor system, Chemosphere, 72 (2008) 1751-1756.

[13] M. Jiang, Y. Zhang, X. Zhou, Y. Su, M. Zhang, K. Zhang, Simultaneous carbon and nutrient removal in an airlift loop reactor under a limited filamentous bulking state, Bioresour. Technol. 130 (2013) 406411.

[14] H. Guo, J. Chen, Y. Li, T. Feng, S. Zhang, Nitrogen and phosphorus removal in an airlift intermittent circulation membrane bioreactor, J. Environ. Sci., 25 (2013) 146-150.

[15] S. Penha, M. Matos, F. Franco, Evaluation of an integrated anaerobic/aerobic SBR system for the treatment of wool dyeing effluents, Biodegradation. 16 (2005) 81-89.

[16] I.K. Kapdan, R. Oztekin, The effect of hydraulic residence time and initial COD concentration on color and COD removal performance of the anaerobic-aerobic SBR system, J. Hazard. Mater.136 (2006) 896-901.

[17] S. Sirianuntapiboon, K. Prasertsong, Treatment of molasses wastewater by acetogenic bacteria BP103 in sequencing batch reactor (SBR) system, Bioresour. Technol. 99 (2008) 1806-1815.

[18] E.B. Gomes, R.F. Silva, A.S. Rosado, N. Pereira Jr, Biotreatment of diesel waste by sequencing batch bioreactor operation mode (SBR), Int. Biodeterior. Biodegrad. 64 (2010) 413-417.

[19] V. Piemonte, L. Di Paola, S. Chakraborty, A. Basile, Sequencing batch reactors (SBRs) for BioH2 production: Reactor operation criteria, Int. J. Hydrogen Energy. 39 (2014) 4863-4869.

[20] G. Moussavi, M. Mahmoudi, B. Barikbin, Biological removal of phenol from strong wastewaters using a novel MSBR, Water Res. 43 (2009) 1295-1302. 
[21] Y. Rahimia, A. Torabiana, N. Mehrdadia, B. Shahmoradi, Simultaneous nitrification-denitrification and phosphorus removal in a fixed bed sequencing batch reactor (FBSBR), J. Hazard. Mater. 185 (2011) 852-857.

[22] S. Yanga, F. Yanga, Z. Fua, T. Wanga, R. Lei, Simultaneous nitrogen and phosphorus removal by a novel sequencing batch moving bed membrane bioreactor for wastewater treatment, J. Hazard. Mater. 175 (2010) 551-557.

[23] A. Asadi, A. Zinatizadeh, S. Sumathi, Simultaneous removal of carbon and nutrients from an industrial estate wastewater in a single up-flow aerobic/anoxic sludge bed (UAASB) bioreactor, Water Res., 46 (2012) 4587-4598.

[24] A. Asadi, A. Zinatizadeh, M. Hasnain Isa, Performance of intermittently aerated up-flow sludge bed reactor and sequencing batch reactor treating industrial estate wastewater: A comparative study, Bioresour. Technol. 123 (2012) 495-506.

[25] S. Rezaee, A.A.L. Zinatizadeh, A. Asadi, High rate CNP removal from a milk processing wastewater in a single ultrasound augmented up-flow anaerobic/aerobic/anoxic bioreactor, Ultrason. Sonochem. 23 (2015) 289-301.

[26] R.C. Jin, P. Zheng, Q. Mahmood, L. Zhang, Performance of a nitrifying airlift reactor using granular sludge, Sep. Purif. Technol., 63 (2008) 670-675.

[27] M. Qingjuan, Y. Fenglin, L. Lifen, M. Fangang, Effects of COD/N ratio and DO concentration on simultaneous nitrifcation and denitrifcation in an airlift internal circulation membrane bioreactor, J. Environ. Sci., 20 (2008) 933-939.

[28] W.E. Federation, A.P.H. Association, Standard methods for the examination of water and wastewater, American Public Health Association (APHA): Washington, DC, USA, (2005).

[29] D.C. Montgomery, Design and Analysis of Experiments, Wiley, New York 1991.

[30] R.L. Mason, R.F. Gunst, J.L. Hess, Statistical Design and Analysis of Experiments, eighth applications to engineering and science, Wiley, New York 2003.

[31] R. Kuehl, Design of Experiments: Statistical principles of research design and analysis, in, C. A: Duxbury press, 2000.

[32] A.I. Khuri, J.A. Cornell, Response surfaces: designs and analyses, CRC press, 1996.

[33] S. Chamoli, ANN and RSM approach for modeling and optimization of designing parameters for a V down perforated baffle roughened rectangular channel, Alexandria Eng. J. (2015).

[34] L.G.B. Pinho, J.S. Nobre, J.M. Singer, Cook's distance for generalized linear mixed models, Comput. Stat. Data Anal. 82 (2015) 126-136.

[35] J. Merchuk, F. Garcia Camacho, Bioreactors: airlift reactors, Encyclopedia of Industrial Biotechnology, (1999).

[36] W.A.J. van Benthum, R.G.J.M. van der Lans, M.C.M. van Loosdrecht, J.J. Heijnen, The biofilm airlift suspension extension reactor - II: Three-phase hydrodynamics, Chem. Eng. Sci. 55 (2000) 699-711.

[37] G.Z. Breisha, J. Winter, Bio-removal of nitrogen from wastewaters-A review, J. Am. Sci., 6 (2010) 508-528.

[38] X. Wang, S. Wang, T. Xue, B. Li, X. Dai, Y. Peng, Treating low carbon/nitrogen (C/N) wastewater in simultaneous nitrification-endogenous denitrification and phosphorous removal (SNDPR) systems by strengthening anaerobic intracellular carbon storage, Water Res. 77 (2015) 191-200.

[39] R. Lemaire, Z. Yuan, N. Bernet, M. Marcos, G. Yilmaz, J. Keller, A sequencing batch reactor system for high-level biological nitrogen and phosphorus removal from abattoir wastewater, Biodegradation, 20 (2009) 339-350.

[40] R.I. Sedlak, Phosphorus and Nitrogen Removal from Municipal Wastewater: Principles and Practice, CRC Press, 1991.

[41] B.M. Wilén, Variation in dissolved oxygen concentration and its effect on the activated sludge properties studied at a full scale wastewater treatment plant, in: In the proceedings of IWA World Water Congress \& Exhibition, 19-24 September 2010 in Montreal, 2010. 
[42] H.N. Chang, R.K. Moon, B.G. Park, S.J. Lim, D.W. Choi, W.G. Lee, S.L. Song, Y.H. Ahn, Simulation of sequential batch reactor (SBR) operation for simultaneous removal of nitrogen and phosphorus, Bioprocess. Eng. Bioprocess. Eng. 23 (2000) 513-521.

[43] H. Kim, O.J. Hao, T.J. McAvoy, Comparison between Model-and pH/ORP-Based Process Control for an AAA System, Tamkang J. Sci. Eng. 3 (2000) 165-172.

[44] G. Liu, X. Xu, L. Zhu, S. Xing, J. Chen, Biological nutrient removal in a continuous anaerobicaerobic-anoxic process treating synthetic domestic wastewater, Chem. Eng. J. 225 (2013) 223-229.

[45] S.R. Chae, S.T. Kang, Y. Watanabe, H.S. Shin, Development of an innovative vertical submerged membrane bioreactor (VSMBR) for simultaneous removal of organic matter and nutrients, Water Res. 40 (2006) 2161-2167.

[46] A. Guadie, S. Xia, Z. Zhang, W. Guo, H.H. Ngo, S.W. Hermanowicz, Simultaneous removal of phosphorus and nitrogen from sewage using a novel combo system of fluidized bed reactor-membrane bioreactor (FBR-MBR), Bioresour. Technol. 149 (2013) 276-285.

[47] M. Jamshidi, Aerobic granular sludge in a single bioreactor with CFID regime, in, Razi university, Kemanshah, Iran, 2014.

[48] A. Nouri, Simultanouse CNP removal in a single up flow aerobic/anoxic bioreactor with CFID regime and a movable aerator, in, Razi university, Kermanshah, Iran, 2014. 